\title{
Home Bias in Bank Sovereign Bond Purchases and the Bank-Sovereign Nexus*
}

\author{
Desislava C. Andreeva and Thomas Vlassopoulos \\ European Central Bank
}

\begin{abstract}
We study whether a pre-existing link between bank and sovereign credit risk biased euro-area banks' sovereign debt portfolio choices at the turn of 2011-12, a period of exceptional increases in their domestic sovereign bond holdings. When bank and sovereign creditworthiness are correlated and sovereign credit risk is elevated, incentives to "shift risk" may render domestic sovereign bonds more attractive than other liquid assets. By investing in domestic government bonds, banks can earn the full risk premium while the risk itself is largely borne by their creditors, as it materializes in states of the world where the banks are likely to be insolvent anyway. Using a bank-level data set, we find evidence that this mechanism can explain a significant part of the purchases of domestic sovereign bonds in the final quarter of 2011 and the first quarter of 2012.
\end{abstract}

JEL Codes: G01, G11, G21, H6.

\section{Introduction}

The financial crisis that has beleaguered the world economy since 2008 has had a distinct effect on euro-area monetary financial institutions' (MFIs)1 1 holdings of government debt. Shortly after the initial shock of the collapse of Lehman Brothers in October 2008, euro-area banks started buying sizable amounts of euro-area government debt (see figure 1). This development was reflecting "flight

*This paper should not be reported as representing the views of the ECB. The views expressed are those of the authors and do not necessarily reflect those of the ECB. We acknowledge helpful comments from J. Sousa, B. Fischer, the participants in a workshop held at the Banque de France, and two anonymous referees. All remaining errors and omissions are our own. Author e-mails: Desislava.Andreeva@ecb.europa.eu and Thomas.Vlassopoulos@ecb.europa.eu.

${ }^{1}$ The terms MFIs and banks are used interchangeably in this paper. 
Figure 1. Purchases of Euro-Area Government Bonds by Euro-Area Banks (twelve-month flows in EUR bn)

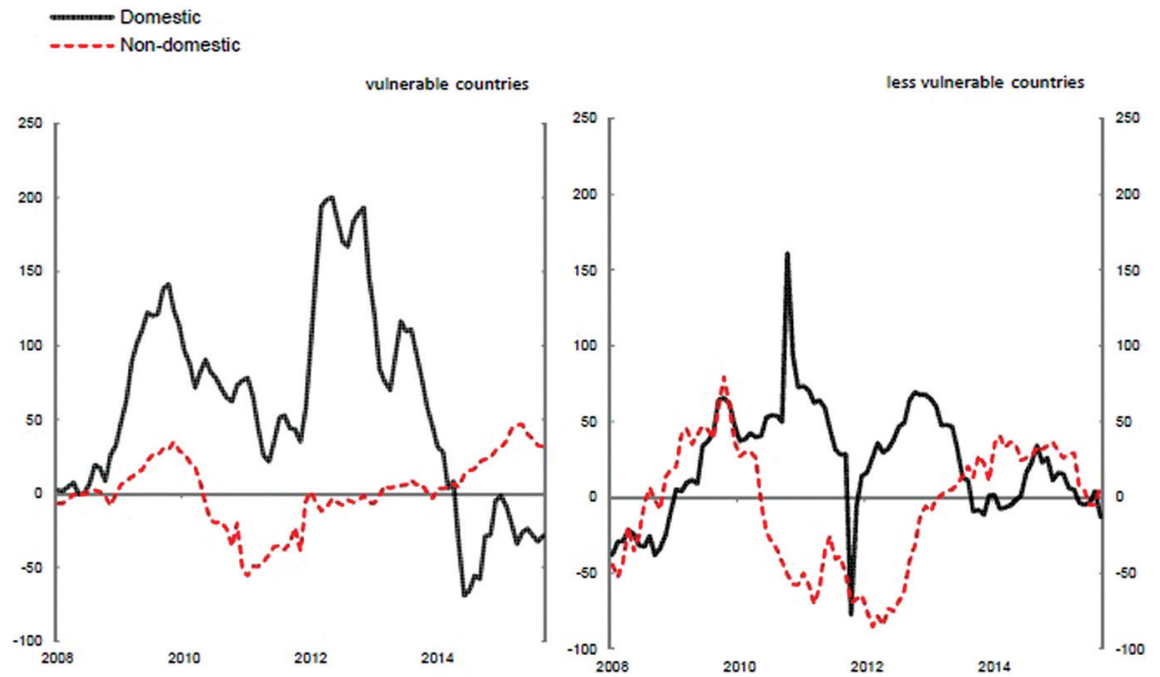

to safety" behavior, as a range of other financial assets had proved to be much riskier than previously perceived. In this initial stage, the discrimination between domestic government bonds and those issued by other euro-area governments was not absolute, as banks were acquiring both types of debt.

With the onset of the euro-area sovereign debt crisis, however, this changed in a dramatic way. Banks started to only acquire domestic government bonds, shedding those issued by other euro-area sovereigns. Importantly, while banks in both vulnerable 2 and lessvulnerable euro-area countries were engaged in this type of activity, the magnitude of purchases by the banks in vulnerable countries was much higher. Indeed, there is a positive correlation between the expansion of domestic sovereign bond portfolios by banks at the height of the sovereign debt crisis and sovereign credit risk, as measured by sovereign CDS spreads (figure 2).

\footnotetext{
${ }^{2}$ Throughout this paper the term "vulnerable countries" refers to Ireland, Greece, Spain, Italy, Cyprus, Portugal, and Slovenia, while the term "lessvulnerable countries" refers to the remaining euro-area countries.
} 
Figure 2. Change in the Stock of Domestic Sovereign Bonds Held by MFIs and Sovereign CDS Spreads at the Height of the Sovereign Debt Crisis

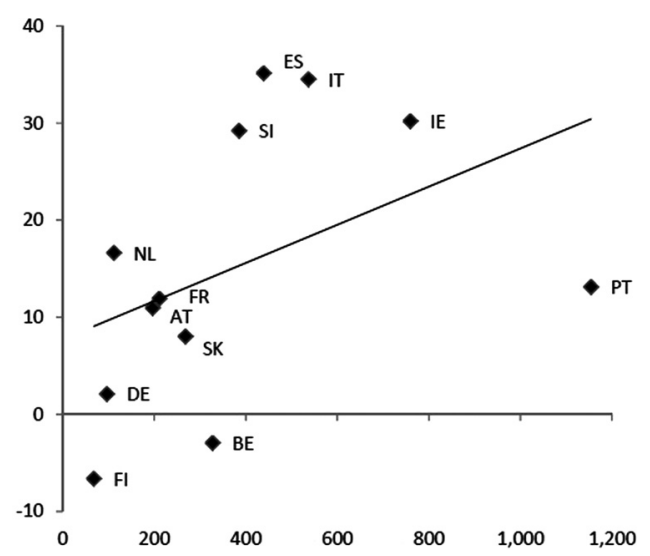

Notes: The change in the stock of domestic sovereign bonds held by MFIs refers to the period between November 2011 and July 2012 and is shown on the y-axis in percentage points. The sovereign CDS spread is the average of daily observations in November 2011 and is shown on the $\mathrm{x}$-axis in basis points.

This paper aims to explain the reemergence of home bias in the acquisition of sovereign bonds by euro-area banks during the sovereign debt crisis. A crucial element in the proposed explanation is the fact that, during this episode, the creditworthiness of some euro-area banks became intertwined with that of their respective sovereign. A large and expanding body of literature looks at the reasons for the emergence of this correlation between bank and sovereign creditworthiness, labeled the bank-sovereign nexus. In this paper, instead, the focus is narrowed down to a specific question: how the presence of a bank-sovereign nexus affects banks' sovereign bond portfolio choices.

We illustrate in a simple theoretical model how the existence of a bank-sovereign nexus tilts the risk-return calculus of banks in favor of domestic sovereign bonds. The home bias arises as bank shareholders earn the credit risk premium on domestic sovereign debt while the underlying credit risk materializes in states of the world in which the bank has a material chance of being insolvent anyway. A portion of sovereign credit risk is, therefore, shifted to 
bank creditors and not internalized in the bank's portfolio allocation decision. The model suggests that incentives to invest in domestic sovereign debt are stronger when, first, the probability of default of the domestic sovereign is higher and, second, the bank-sovereign nexus is stronger. In the first case, the credit risk premium that can be collected is larger, while, in the second, a greater portion of credit risk is shifted to bank creditors.

Such incentives to shift risk can explain why "carry trades in peripheral bonds" 3 - an investment strategy that was in principle open to all euro-area banks - was in fact only pursued by banks located in vulnerable countries and focused on domestic sovereign bonds, rather than the sovereign bonds with the highest yields. We argue that non-domestic banks tended to regard these high yields as reflecting an increase in the corresponding riskiness of sovereign bonds. In risk-adjusted terms, the return from carry trades in peripheral bonds for non-domestic banks was therefore very low, if positive at all. By contrast, domestic banks did not internalize the elevated credit risk of these bonds fully, as their own probability of becoming insolvent was closely linked to the one of the domestic sovereign.

The main part of this paper tests the predictions of the simple theoretical model empirically using a novel bank-level data set. We focus, in particular, on the period when two longer-term refinancing operations with a maturity of three years were introduced by the European Central Bank (ECB). In this period banks stepped up their acquisitions of domestic government bonds in a context of elevated pricing of sovereign credit risk for vulnerable euro-area countries. Panel regressions based on individual bank data reveal that the incentive mechanism described above is a significant determinant of domestic sovereign bond purchases during this episode. The empirical analysis also shows, however, that this mechanism is not relevant on average over the entire sample considered (spanning 2008:Q1 to 2015:Q2), as it requires the coexistence of non-trivial levels of sovereign credit risk and a material intensity of the bank-sovereign nexus to become relevant.

In the next section we place our paper in the context of the related literature before introducing our simple theoretical

\footnotetext{
${ }^{3}$ The acquisition of peripheral sovereign bonds funded via repos from the central bank.
} 
framework in section 3. Subsequently, we outline our empirical strategy and describe the data sources in section 4 . Section 5 presents the results of our empirical analysis, while section 6 concludes.

\section{The Academic Debate on the Bank-Sovereign Nexus}

The recent literature on sovereign credit risk and domestic bank fragility can be grouped into three strands.

A first strand identifies a number of channels that give rise to a co-movement of bank and sovereign credit risk premiums 4 First, risk is transmitted from sovereigns to banks via holdings of government debt. The value of banks' claims on the sovereign diminishes whenever the creditworthiness of the domestic government deteriorates, linking the market prices of bank and sovereign credit risk. Such direct exposures are studied in Bolton and Jeanne (2011), Cooper and Nikolov (2018), and Gennaioli, Martin, and Rossi (2014). The channel running from sovereigns to banks is also relevant for banks' liabilities. This operates through the erosion of the value of sovereign bonds used as collateral in secured funding transactions, the rating downgrades for sovereign bonds that act as a ceiling for the rating of private debt, and the reduction in the perceived value of implicit or explicit government guarantees on bank debt (Acharya, Drechsler, and Schnabl 2014). Second, national financial safety nets transmit risk from banks to sovereigns as bank bailouts and guarantees on bank liabilities weaken sovereign creditworthiness (Attinasi, Checherita, and Nickel 2010; Dieckmann and Plank 2012; Ejsing and Lemke 2011; Gerlach, Schulz, and Wolff 2010; and Kallestrup, Lande, and Murgoci 2016) and vice versa, from the sovereign to banks, as a weakened sovereign creditworthiness undermines the value of the ultimate fiscal backstops for bank solvency (see, e.g., Cooper and Nikolov 2018). Third, banks and sovereigns are exposed to common factors. The strength of the balance sheet of both depends on the state of the local economy. Bank borrowers are exposed to the same developments in the domestic economy that have placed public finances under pressure. As the creditworthiness of these borrowers

\footnotetext{
${ }^{4} \mathrm{~A}$ more extensive description of these channels is provided, e.g., in Angelini, Grande, and Panetta (2014).
} 
is eroded, so is that of the creditor banks, in tandem with that of the domestic sovereign (see, e.g., European Systemic Risk Board 2015).

The second strand of literature studies the impact of domestic sovereign bond purchases on the supply of credit to the non-financial private sector. Broner et al. (2014) argue that purchases of domestic sovereign bonds crowd out bank credit to the private sector because domestic banks find it difficult to obtain credit from abroad at times of sovereign stress while, in addition, they absorb a larger share of sovereign issuances. In this case, the private and public sector compete for the same, limited, pool of savings. Popov and van Horen (2015) find evidence that banks exposed to stressed euro-area sovereign bonds increased lending in the syndicated loan market much less than non-exposed banks, suggesting a negative impact on credit supply. Becker and Ivashina (2018) document a contraction of bank credit related to the expansion of domestic sovereign debt held by lenders. Finally, Altavilla, Pagano, and Simonelli (2017) find that an increase in sovereign credit risk, owing to the exposures of lenders to government debt, has an economically and statistically significant effect on their lending to the private sector in stressed euro-area countries.

The third strand of literature aims to explain the purchases of domestic sovereign bonds by banks located in euro-area countries under stress. This literature builds on broader explanations of the motivations for banks to hold sovereign bonds, over and above their expected pecuniary returns. Gennaioli, Martin, and Rossi (2014) maintain that banks hold government bonds as a buffer against the materialization of liquidity shocks, in the spirit of Holmstrom and Tirole (1993). Other authors, such as Bonner (2016) and Popov and van Horen (2015) highlight the relevance of the preferential treatment of government bonds in bank capital and liquidity regulation as a driver for holding government bonds. As regards home bias, a number of considerations apply, which are relevant beyond the specific setting of the euro-area sovereign debt crisis and indeed beyond sovereign debt. Angelini, Grande, and Panetta (2014) cite hedging motives (e.g., for exchange rate risk or in the context of broader asset-liability management), transaction costs, legal risk, and informational frictions as potential reasons for a home bias in sovereign bond purchases by banks. 
In the specific case of bank purchases of domestic government bonds during the euro-area sovereign debt crisis, the explanations can be separated into three groups: a set that is centered on the government exercising moral suasion or financial repression; a set that highlights moral hazard in bank behavior; and a third set of more heterogeneous explanations that highlight other, often complementary, factors.

Moral suasion and financial repression refer to government policies or practices intended to apply pressure to the domestic financial sector to absorb government debt issuance 5 Among the proponents of the financial repression hypothesis is Uhlig (2014), who argues that supervisory rules induce banks in countries with weak fiscal fundamentals to purchase domestic bonds and refinance these via repos with a multilateral central bank. Becker and Ivashina (2018) find evidence that direct government ownership as well as influence via banks' boards of directors are channels used to exercise financial repression. Similarly, Horvath, Huizinga, and Ioannidou (2015) report evidence that home bias in government bond purchases is higher for banks owned by risky sovereigns. Acharya and Rajan (2013) argue that myopic governments might repress their domestic lenders to hold large amounts of domestic sovereign debt so as to secure access to external financing. In their model, large holdings of domestic sovereign bonds by the local banking sector make a sovereign default very costly for the government. Therefore, financial repression serves to both channel domestic savings to the sovereign and to reassure foreign creditors that the government is willing to pay back its outstanding debt 6

The second set of explanations centers on a particular case of moral hazard, dubbed risk shifting. In this narrative, bank purchases of government debt are motivated by the aim to maximize expected returns for bank shareholders, i.e., a voluntary, optimal

\footnotetext{
${ }^{5}$ Becker and Ivashina (2018) trace the origins of the term "financial repression" to McKinnon (1973) and Shaw (1973).

${ }^{6}$ A very similar argument is put forward by Broner et al. (2014). They argue that the expected returns on sovereign debt are higher for domestic creditors at times of fiscal stress because sovereigns are less likely to default on them. Thus, the share of sovereign debt absorbed by domestic agents increases when sovereign credit risk is higher - however, contrary to Acharya and Rajan's (2013) conclusion, without any financial repression.
} 
portfolio choice rather than an investment imposed by government action. Because of limited liability, the payoff structure of bank portfolio decisions is asymmetric for bank shareholders in the sense that the downside is capped by their participation in the capital of the bank, while the upside is not restricted. Accordingly, risk can be shifted from bank shareholders to bank creditors 7 Consistent with this view, Horvath, Huizinga, and Ioannidou (2015) find that home bias in sovereign bond purchases is greater if bank corporate governance regimes are more shareholder friendly. A particular case of risk shifting is "gambling for resurrection," whereby poorly performing or undercapitalized banks have added incentives to engage in high-risk investments, as they are failing anyway. Risk shifting by undercapitalized banks is among the driving factors of domestic sovereign bond purchases in Acharya and Steffen (2015). They focus on banks' incentives to fund long-term bonds issued by euroarea sovereigns under stress via short-term unsecured funding and earn the carry spread. In addition to risk shifting, their empirical analysis identifies regulatory capital arbitrage and the availability of Eurosystem funding in full allotment mode as factors that induce banks to engage in carry trades. Crosignani (2015) emphasizes the interrelationship between the tendency of undercapitalized banks to invest in assets whose returns materialize in good states of the world - like domestic sovereign debt - and the willingness of governments to recapitalize banks. Sovereigns with difficult access to financial markets might be unwilling to recapitalize weak (but still solvent) domestic banks so that the latter will continue to act as buyers of last resort of government debt, which they would be less inclined to do if they were well capitalized. In principle, risk shifting could also involve the purchase of government bonds issued by other (non-domestic) risky sovereign issuers. Farhi and Tirole (2018) show, however, that as long as bank balance sheet and fiscal shocks within one country are at least slightly positively correlated and fiscal shocks across countries are not perfectly correlated, risk shifting will concentrate entirely on domestic sovereign bonds.

\footnotetext{
${ }^{7}$ The classic risk-shifting or asset substitution problem was first studied in Jensen and Meckling (1976). They show that shareholders of a firm can transfer wealth from its debtors by engaging in risky projects.
} 
Other explanations stress motivations that emerged or were exacerbated during the euro-area sovereign debt crisis but do not rest on financial repression or risk shifting. Some authors (Angelini, Grande, and Panetta 2014; Battistini, Pagano, and Simonelli 2014; European Systemic Risk Board 2015) highlight the emergence of redenomination risk in the euro area, which may have prompted some banks to match assets and liabilities at the domestic level in order to hedge themselves 8 Another explanation in this third set emphasizes the lower demand for credit from the private sector in the countries most affected by the crisis, which may have induced domestic banks to step up their investment in sovereign bonds (European Systemic Risk Board 2015). This motivation on its own, however, does not explain the home bias in sovereign bond purchases. This also applies to the explanation that highlights the precautionary motive, i.e., the use of Eurosystem borrowing to prefund the repayment of maturing debt, placing the liquidity obtained in sovereign bonds in the meantime (Bank of Italy 2012, 2013).

In our paper the existence of a bank-sovereign nexus - as identified in the first strand of literature - is taken as the starting point for the analysis. The precise reasons that may have led to the development of this nexus are not important for the analysis. The conclusions hold regardless of whether the original cause of the nexus was bank exposure to the sovereign or any of the other plausible reasons previously cited. Our analysis contributes to the third strand of the literature by postulating and empirically confirming (using a bank-level data set) that once a bank-sovereign nexus has developed, it generates economic incentives for home bias in government bond purchases by banks. This implies that if the creditworthiness of banks and the sovereign are somehow intertwined, home bias emerges as an optimizing economic choice. While, therefore, the analysis presented in this paper does not rule out that the "original sin" giving rise to the bank-sovereign nexus may have been financial repression, it argues that a potent self-feeding mechanism rooted in risk shifting induces banks to expand their exposures

\footnotetext{
${ }^{8}$ In addition, concerns that non-domestic creditors might be treated less favorably than domestic ones in a euro-area breakup scenario may have further motivated a home bias in sovereign bond purchases.
} 
vis-à-vis the domestic government further as soon as sovereign credit risk increases.

\section{A Simple Model}

We use a very simple model to illustrate how the presence of a banksovereign nexus affects banks' pricing of domestic sovereign bonds. This illustration is intended to motivate the main contribution of our paper, which is the empirical validation provided in the next sections that the purchases of domestic sovereign bonds by euro-area banks during the final quarter of 2011 and the first quarter of 2012 to a large extent reflect risk-shifting considerations.

We consider two countries and two banks headquartered in each of the countries. Sovereigns issue zero-coupon bonds with a face value of 1 . They do not honor their obligations in all states of the world. For simplicity, we assume that the haircut in case of sovereign default is 100 percent. Banks are leveraged and subject to limited liability.

Let $D_{k}^{j}=\{0,1\}$ be a variable equal to 1 if default occurs. The subscript $k=\{s, b\}$ denotes either a sovereign $(k=s)$ or a bank $(k=b)$; the superscript $j=\{x, y\}$ denotes the country $-x$ or $y$. Domestic bank and sovereign defaults are assumed to be correlated. As discussed in section 2, there are several rationales for this assumption 9 By contrast, the default of the foreign sovereign is assumed to effectively have no bearing on the probability of default of the bank 10

\footnotetext{
${ }^{9}$ To recall, first, domestic banks may have lent to their sovereigns. Second, sovereigns are the ultimate backstops in a domestic banking crisis, providing deposit insurance and capital injections to contain systemic risk. And third, the strength of the balance sheet of both the domestic banks and the sovereign depends on the state of the local economy.

${ }^{10}$ The possibility that the probability of default of one sovereign is correlated to that of another one implies that a correlation of domestic bank and sovereign defaults may also introduce some correlation between the bank and a nondomestic sovereign. Farhi and Tirole (2018) have shown, however, that as long as the correlation of fiscal shocks across sovereigns is not perfect, risk shifting into domestic sovereign bonds dominates. In view of this and for presentational simplicity, we abstract from the possibility that a default of a non-domestic sovereign affects the probability of default of the bank.
} 
We, therefore, posit that the probability of a bank default has the following form:

$$
\operatorname{Pr}\left(D_{b}^{j}=1\right)=\alpha^{j}+\gamma^{j} \operatorname{Pr}\left(D_{s}^{j}=1\right) .
$$

Here $\gamma^{j}$ captures the strength of the sovereign-bank nexus, while the idiosyncratic component in bank credit risk is reflected in $\alpha^{j}$.

We denote the risk-free rate with $r$ and assume that there are risk-neutral, non-leveraged investors who purchase sovereign and bank bonds in competitive markets. The assumption implies that in equilibrium the expected returns of the two sovereign bonds will equal $r$ :

$$
1+r=\operatorname{Pr}\left(D_{s}^{j}=0\right)\left(1+i_{s}^{j}\right), \text { for } j=\{x, y\},
$$

where $i_{s}^{j}$ denotes the yield on sovereign bonds issued by country $j$. It is implicitly assumed that banks are not the marginal investors in sovereign bonds.

From the perspective of bank shareholders in country $x$, the expected return from investing in sovereign bonds issued in country $j=\{x, y\}$ is denoted by $R_{s j}^{x}$. For the bank shareholder to receive the payout from the investment in a bond, the bank needs to still be solvent, as otherwise bank shareholders are wiped out. Moreover the sovereign issuer of the bond itself must not have defaulted. Therefore, the expected returns are

$$
R_{s j}^{x}=\operatorname{Pr}\left(D_{b}^{x}=0 \cap D_{s}^{j}=0\right)\left(1+i_{s}^{j}\right) .
$$

This expression can be equivalently written as

$$
R_{s j}^{x}=\operatorname{Pr}\left(D_{b}^{x}=0 \mid D_{s}^{j}=0\right) \operatorname{Pr}\left(D_{s}^{j}=0\right)\left(1+i_{s}^{j}\right),
$$

which, using (2), simplifies to

$$
R_{s j}^{x}=\operatorname{Pr}\left(D_{b}^{x}=0 \mid D_{s}^{j}=0\right)(1+r) .
$$

If the bond invested in has been issued by the domestic sovereign, then conditioning on the sovereign being solvent $\left(D_{s}^{x}=0\right)$ implies through (1) that the expected return is

$$
R_{s x}^{x}=\left(1-\alpha^{x}\right)(1+r) .
$$


It is important to note that the expression capturing the conditional probability of the bank being solvent only contains a term for the idiosyncratic bank risk $\left(\alpha^{x}\right)$ and not one for spillover of domestic sovereign risk $\left(\gamma^{x}\right)$.

By contrast, if the bond invested in has been issued by the foreign sovereign, then conditioning on that sovereign being solvent $\left(D_{s}^{y}=0\right)$ has no bearing on the solvency of the bank, which according to (1) is only linked to the probability of default of the domestic sovereign. In this case the expected return is therefore

$$
R_{s y}^{x}=\left(1-\alpha^{x}-\gamma^{x} d_{s}^{x}\right)(1+r),
$$

where, to simplify the notation, we denote the unconditional probability of default of sovereign $j\left(\operatorname{Pr}\left(D_{s}^{j}=1\right)\right)$ to be $d_{s}^{j}$.

While for the risk-neutral outside investors the two sovereign bonds generate the same expected return given the prevailing market prices, from the perspective of bank shareholders, investment in domestic government bonds promises a higher expected return, with the return differential being equal to

$$
R_{s x}^{x}-R_{s y}^{x}=\gamma^{x} d_{s}^{x}(1+r) .
$$

The differential is positive for $\gamma^{x}>0$ and $d_{s}^{x}>0$. It also increases in both $\gamma^{x}$ and $d_{s}^{x}$. Essentially, bank shareholders earn the full domestic sovereign default risk premium, while a large part of the default risk is borne by bank creditors and not internalized. The expression $\gamma^{x} d_{s}^{x}$ captures the "neglected" portion of domestic sovereign credit risk. A higher probability of domestic sovereign default - a higher $d_{s}^{x}$ - tilts the risk-return calculus in favor of domestic debt because banks can collect a higher risk premium. Similarly, a stronger bank-sovereign nexus - reflected in a high $\gamma^{j}$-leads to stronger incentives to invest in domestic sovereign debt because a larger fraction of the default risk can be shifted to bank creditors 11

\footnotetext{
${ }^{11}$ If the increased risk faced by creditors would be appropriately recognized by them and fully priced in banks' cost of funding, then no net benefit would accrue for bank shareholders. In practice, however, this risk is unlikely to be fully priced in, owing, for instance, to deposit insurance which reduces the sensitivity of deposit funding costs to banks' risk profile (Demirguc-Kunt and Huizinga 2004).
} 


\section{Empirical Strategy}

The crucial prediction emerging from the preceding theoretical analysis is that banks face incentives to invest in domestic sovereign debt when their own default probability is strongly linked to that of the domestic sovereign and the probability of default of their respective sovereign is higher. In this section we set out our strategy for empirically testing this prediction.

To transpose the theoretical prediction to one that is testable, we need to map the strength of the incentives to invest in domestic sovereign debt - a concept that is not observable - to a measurable bank behavior. In the empirical analysis we focus on observed bank purchases of domestic government bonds. The tested hypotheses thus are that (i) conditional on a strong bank-sovereign nexus, banks acquire more domestic government bonds the riskier the sovereign issuer is and, (ii) conditional on high domestic sovereign credit risk, domestic sovereign bond purchases increase the stronger the bank-sovereign nexus is.

To test the hypotheses, we exploit the cross-sectional variation in the extent to which a bank's solvency is linked to that of its respective sovereign using bank-level data and the variation in credit risk in domestic sovereign bonds. For bank purchases of domestic sovereign bonds and other bank balance sheet information, we use a confidential data set of selected balance sheet indicators for a sample of individual MFIs, collected for the compilation of the aggregate monetary statistics. The MFIs included in the data set account for approximately 70 percent of total outstanding amounts of main assets of euro-area MFIs. The main assets of MFIs located in vulnerable euro-area countries account for 34 percent of our sample. This share is comparable to the share of 30 percent in the overall reporting population. The data is available at a monthly frequency starting in June 2007. It is converted to quarterly frequency in this analysis to match that of some of the macroeconomic data also used and to reduce excessive volatility in balance sheet flow data.

In addition, testing the theoretical prediction requires a measure of the strength of the nexus between each bank and the respective sovereign, which is not directly observable. The first step in our empirical strategy is, therefore, to construct such a measure. We employ five-year credit default swap (CDS) spreads for the banks 
in our sample and the respective sovereigns, obtained from Datastream, Reuters, and Bloomberg.12 CDS spreads are a market price for the insurance premium against default of a debtor. They, therefore, embody the market evaluation of the debtor's probability of default and the associated loss given default. We construct a measure for $\gamma_{i}$ (the correlation between an individual bank $i$ 's default probability and the probability of default of the respective sovereign) by calculating rolling correlations between each bank's CDS spread and the CDS spread of the respective sovereign over a backwardlooking twelve-month window 13 In keeping with this approach, we use the CDS spread on each sovereign to measure its probability of default $\left(d_{s i}\right) 14$ In the empirical analysis the sovereign CDS spread is used in demeaned form (across time and countries).

The proxy used for $\gamma_{i}$ represents a faithful mapping of the theoretical concept to the empirical domain. This, however, comes at a cost, as the proxy requires the use of quoted CDS spreads. These are only available for a subset of the banks included in our sample, thereby reducing our cross-section to 120 banks.

As shown in equation (8), the product of each bank's nexus with its respective sovereign and the probability of sovereign default linearly increases the ex ante return differential in favor of domestic

\footnotetext{
${ }^{12}$ In cases where an entity in our sample is part of an international banking group, the domestic jurisdiction is the one where this entity is located and not that of its parent. As CDS are not typically observed for such sub-group entities, the CDS of the parent group is used. This is consistent with the logic of the theoretical model, as in such cases the capital backstop is primarily provided by the parent.

${ }^{13}$ This correlation should be a good measure for $\gamma$, to the extent that the loss given default of both the bank and the sovereign does not contribute significantly to the variability in the respective CDS spread. Indeed, it is common practice in the literature to assume a constant loss given default (or, equivalently, recovery rate) when extracting estimates of probabilities of default from CDS; see, for instance, Lucas, Schwaab, and Zhang (2013) and Radev (2013). Moreover, the linear relationship between the CDS spread and the probability of default that is implied by this calculation is a good approximation only for non-distressed debtors (Radev 2013). Partly for this reason, we have excluded selected distressed banks and countries (Greece, Cyprus) from our analysis.

${ }^{14}$ The assumption made in section 3 of a 100 percent loss given sovereign default (or 0 percent recovery rate) simplifies the interpretation of the CDS spread as a market-based evaluation of $d_{s}$. Strictly speaking, however, to derive an accurate market-based measure of the probability of default from CDS spreads would require implementing the procedure described in O'Kane (2008).
} 
Figure 3. The Strength of Bank $i$ 's Nexus with Its Respective Sovereign Multiplied by the Sovereign CDS Spread $\left(\rho_{i} \equiv \gamma_{i} d_{s i}\right)$

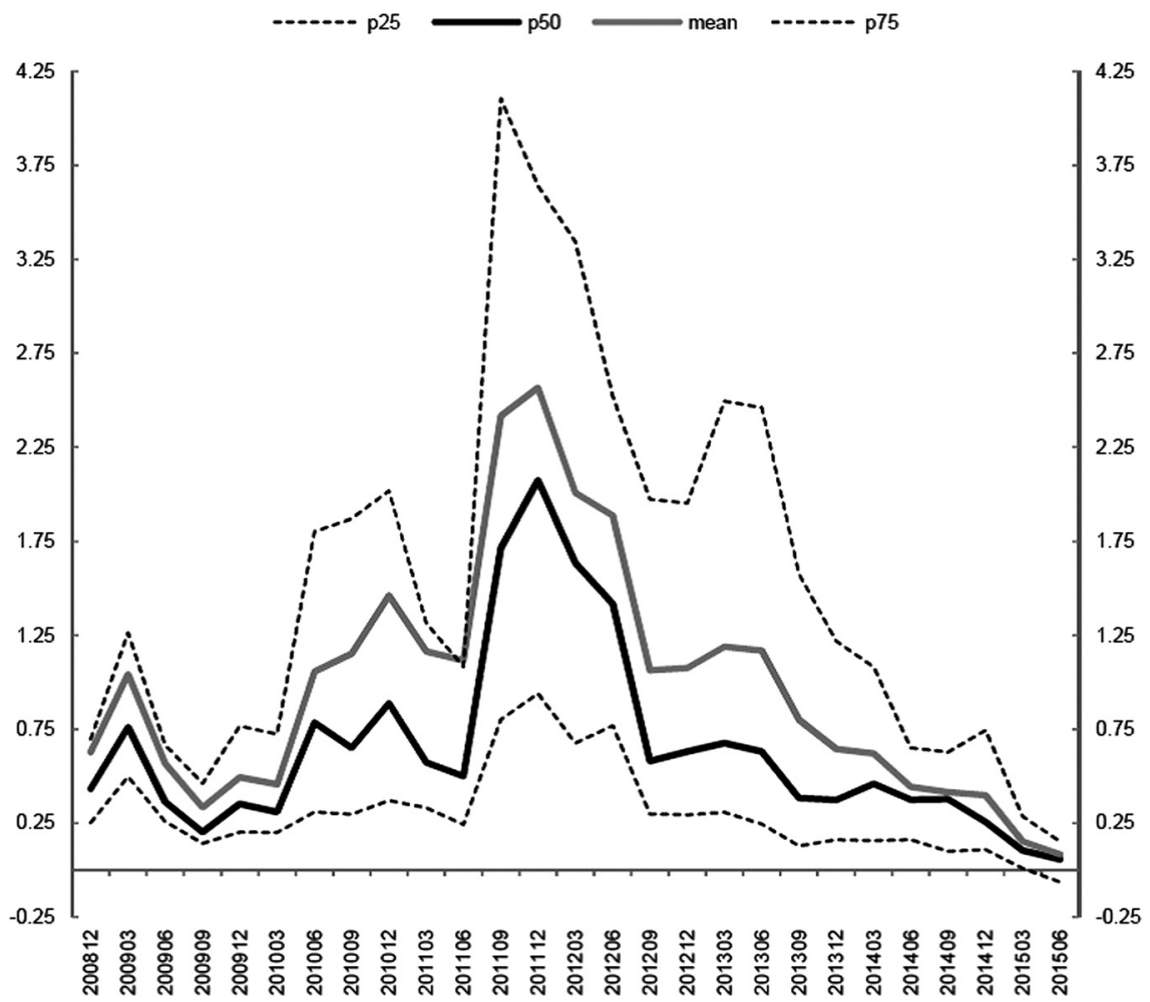

bonds. Therefore, we use $\rho_{i}$ - the interaction between $\gamma_{i}$ and the CDS spread of the respective sovereign $\left(\rho_{i} \equiv \gamma_{i} d_{s i}\right)$ - to capture euro-area banks' incentives for risk shifting via investments in domestic sovereign bonds. Figure 3 depicts the evolution of $\rho_{i}$. Its cross-sectional distribution shifts up only gradually until mid-2011: the median $\rho_{i}$ in June 2011 roughly corresponds to the one observed at the start of the period shown in the figure. During the final two quarters of 2011, however, the median value quadruples 15 Figure 4 reveals that this

\footnotetext{
${ }^{15}$ From 0.5 in June to 2.07 in December 2011.
} 
Figure 4. The Components of $\rho_{i}$

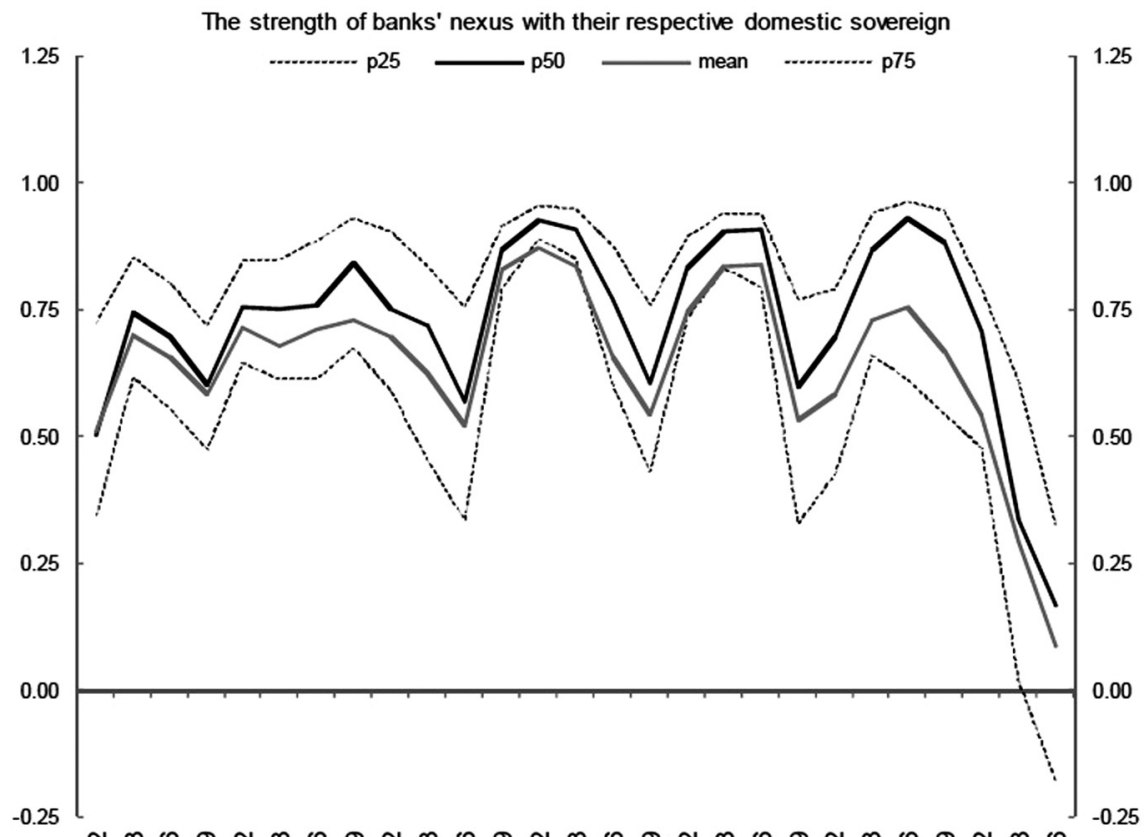

Nㅜㅇ ర্ণ

The evolution of average bank and sovereign CDS spreads

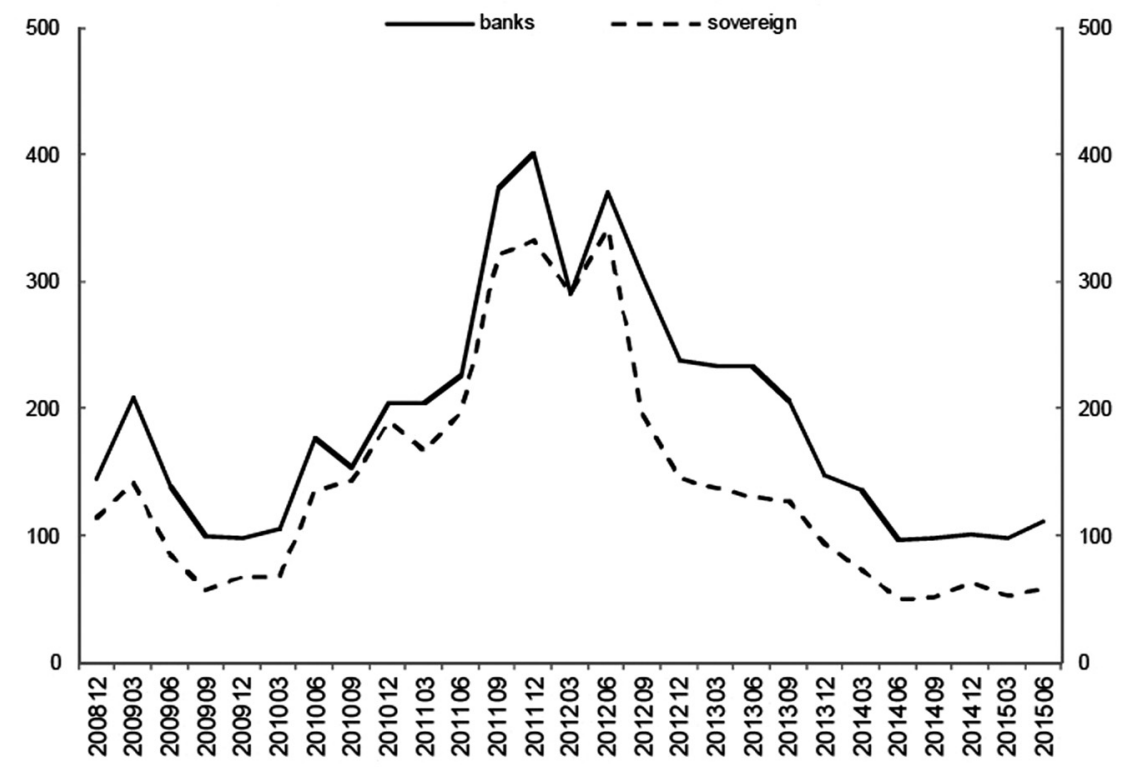


surge reflects increases in both components of $\rho_{i}$. First, the banksovereign nexus $\left(\gamma_{i}\right)$ intensifies for the vast majority of euro-area banks, reflected in a marked increase of the median $\gamma_{i}$ accompanied by a compression of the interquartile range surrounding it (see the upper panel of figure 4). Second, sovereign credit risk, as measured by CDS spreads on bonds issued by euro-area governments, peaks (see the lower panel of figure 41).

We are particularly interested in understanding to what extent the marked acquisition of domestic sovereign bonds by euro-area banks in the period following the introduction of the three-year longer-term refinancing operations by the ECB (labeled VLTROs or three-year LTROs) in December 2011 and until the deescalation of the sovereign debt crisis in July 2012 can be explained by risk shifting via investment in domestic sovereign bonds. These purchases increased euro-area banks' holdings of domestic government bonds by 21 percent. The same episode has been studied by Acharya and Steffen (2015) and Horvath, Huizinga, and Ioannidou (2015), among others.

Having specified measures for $\rho_{i}$ and defined the main period under investigation, we proceed in estimating panel equations of the following type:

$$
B_{i t}=\alpha_{i}+t+\beta_{1} \rho_{i t}+\Gamma X_{i t}+\varepsilon_{i t},
$$

where $B_{i t}$ denotes purchases of domestic government bonds by bank $i$ in quarter $t$. $B_{i t}$ measures changes in holdings of domestic government bonds on the basis of transactions only. Thus, pure valuation effects that can change the reported amount of government bonds held do not not affect our results. To control for unobservable time-invariant bank-specific factors that can affect banks' decisions to purchase domestic sovereign debt, (9) includes bank fixed effects $\left(\alpha_{i}\right)$. In addition, (9) includes a set of time dummies $(t)$ to account for aggregate shocks, such as high uncertainty or market concerns regarding euro-area fragmentation. As previously defined, $\rho_{i t}$ is the product of the strength of bank $i$ 's nexus with its respective sovereign $\left(\gamma_{i t}\right)$ and the demeaned CDS spread of the respective sovereign $\left(d_{s i t}\right)$. The time window over which $\gamma_{i t}$ is calculated precedes the period of the purchases to avoid reverse causality that would arise if a contemporaneous window 
was chosen 16 Finally, $X_{i t}$ denotes a vector of bank- and countryspecific controls intended to capture additional motivations for holding government bonds, which were referred to in section 2. Both $B_{i t}$ and the bank-specific controls included in $X_{i t}$ are defined as ratios to each bank's main assets. We scale by main assets because we are interested in studying changes in banks' portfolio composition, rather than a change in domestic government bond holdings that is proportional to an overall change in the size of the bank 17 Table 1 presents summary statistics for the variables used in our analysis.

\section{Empirical Analysis}

\subsection{Baseline Result}

We estimate regressions of the type given by equation (9), using panel fixed effects for a sample covering the period 2008:Q1 to 2015:Q2. Panel A of table 2 presents a first set of results, focusing exclusively on our main variable of interest - $\rho_{i t}$-and its components - $\gamma_{i t}$ and $d_{s i t}$. The coefficient of $\rho_{i t}$ is not significant on average over the entire period (see column 1) 18 The risk-shifting

\footnotetext{
${ }^{16}$ Using a contemporaneous window is problematic because the increase of banks' direct exposure vis-à-vis their domestic sovereign in general strengthens the bank-sovereign nexus (see the literature cited in section 2). The estimated regression coefficient would therefore be biased upwards and include the causal effect of a stronger nexus on banks' purchases of domestic debt and the feedback effect of increased exposure to the sovereign on the strength of the bank-sovereign nexus. Given that our dependent variable is the flow of government bond purchases, which is not a very persistent variable, the use of a lagged window for the calculation of $\gamma_{i}$ should address any endogeneity issues.

${ }^{17}$ The approach of scaling bank-specific variables by a measure of bank size is standard in empirical banking analysis. For example, Cornett et al. (2011) study how banks manage their holdings of liquid assets, the adjustment of bank lending on the balance sheet, and total credit origination using dependent and explanatory variables scaled by total assets. Our data set does not include total assets; therefore, we measure bank size using main assets. Main assets are total assets less fixed assets and remaining assets, the latter largely comprising financial derivative positions.

${ }^{18}$ All p-values reported in the paper are based on cluster-robust standard errors. Since our analysis includes explanatory variables that do not vary within a country, the clustering is at the country level, as suggested in Bertrand, Duffo, and Mullainathan (2004). The results do not change if instead the standard errors allow for clustering at the level of individual banks.
} 


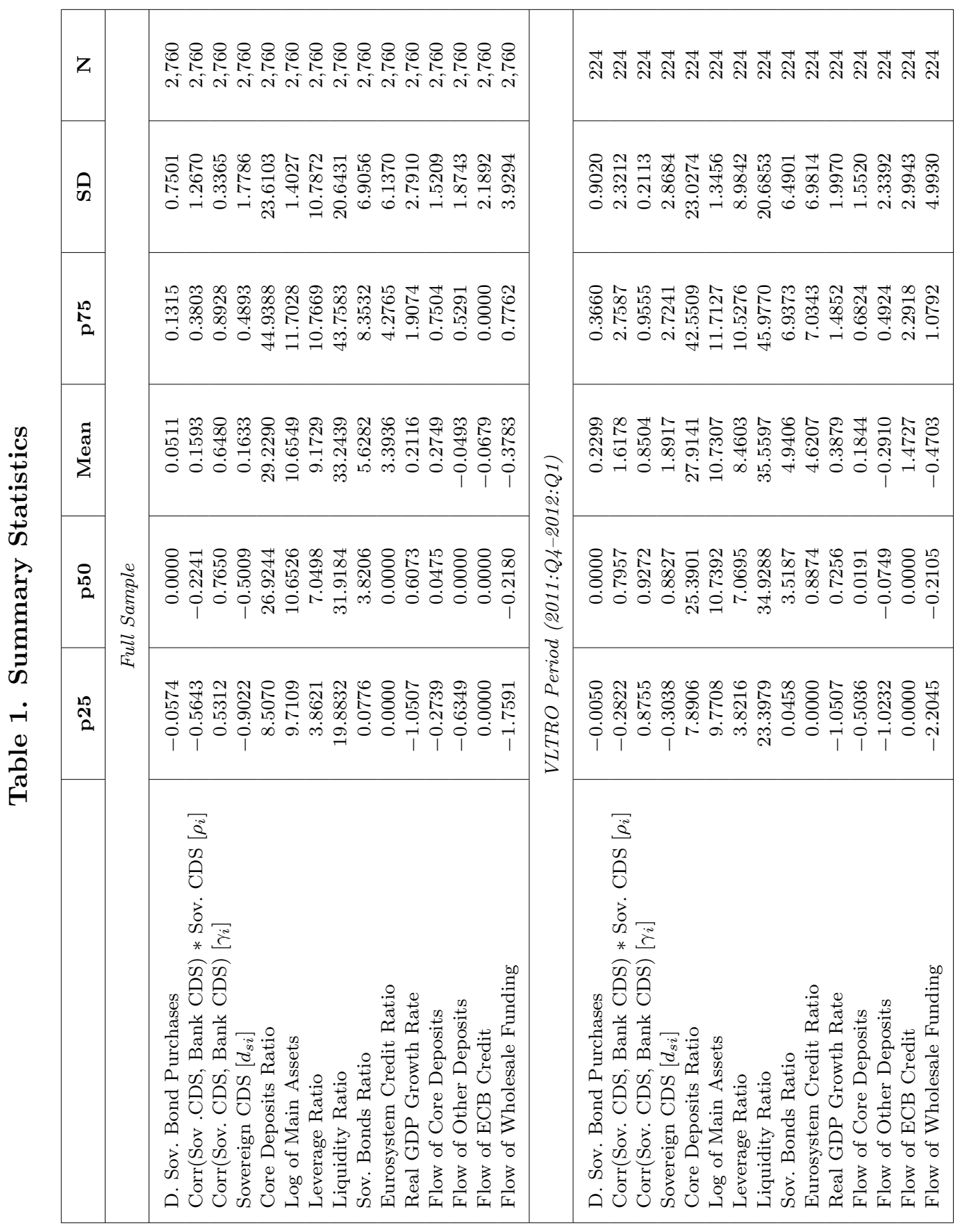




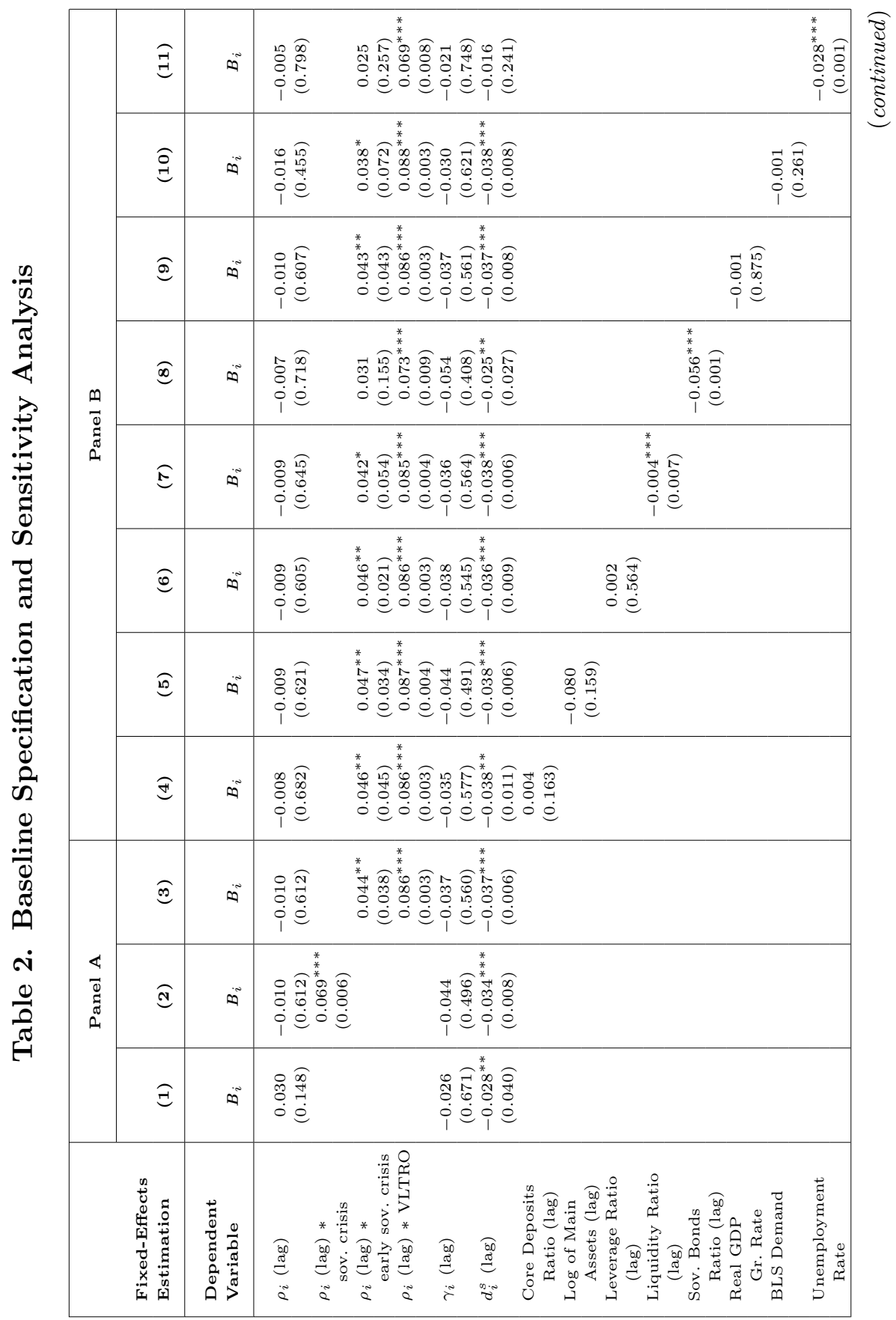




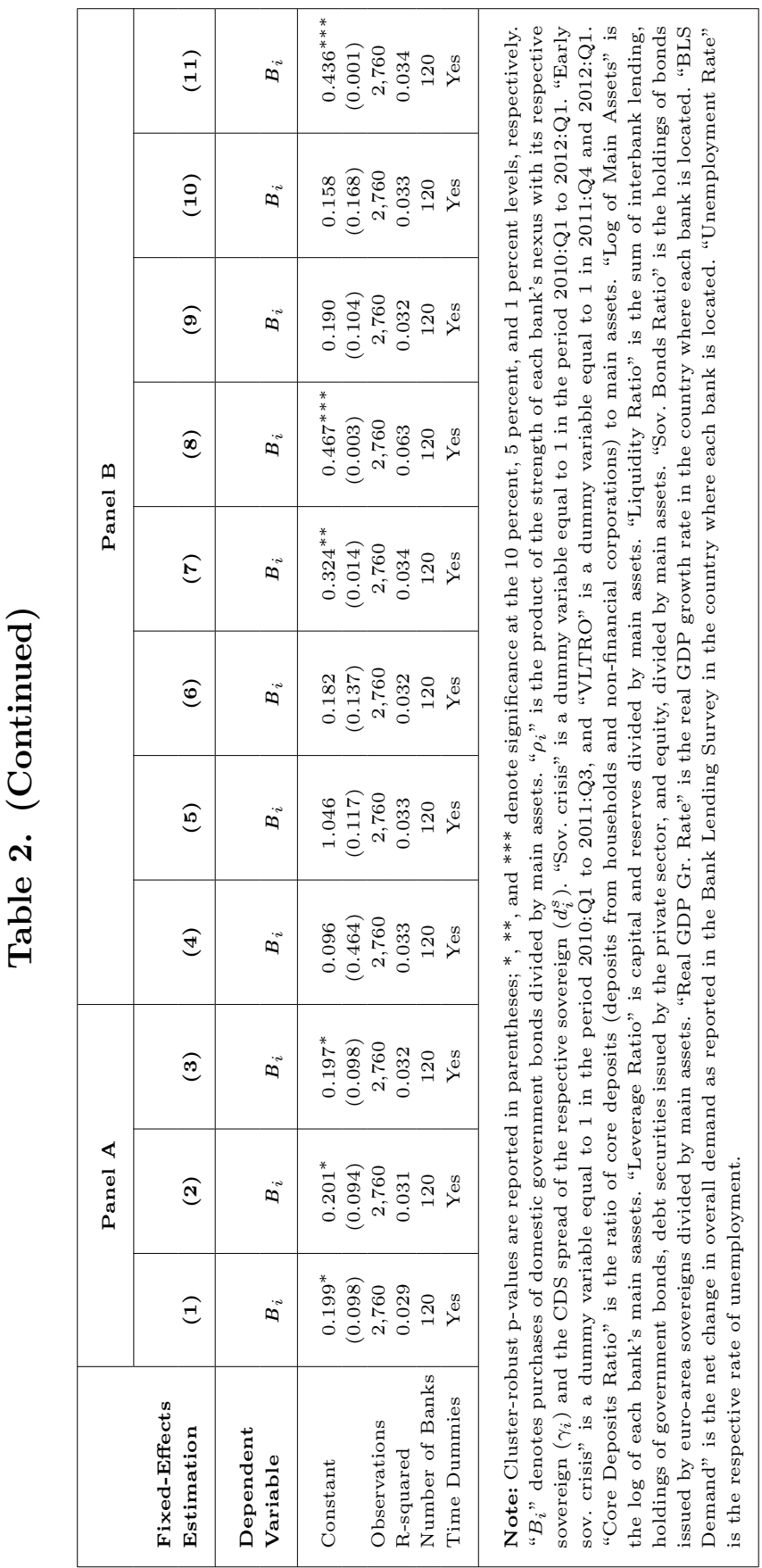


mechanism likely requires the coexistence of non-trivial levels of sovereign credit risk and a material intensity of the bank-sovereign nexus to become relevant. We subsequently include an interaction term of $\rho_{i t}$ and a dummy variable sov. crisis equal to 1 during the sovereign crisis period starting in 2010:Q1 and ending in 2012:Q1, when these conditions were observed (see figures 3 and 44). The interaction term is statistically significant (see column 2 of table 2). The drivers of the observed purchases of domestic government bonds in that period are consistent with the prediction of the simple theoretical framework, thereby supporting the risk-shifting hypothesis.

To separately identify the period we are primarily interested in, we subsequently split the sovereign crisis period into two subperiods, labeled the early sovereign crisis and the VLTRO period. The VLTRO period comprises the final quarter of 2011 and the first quarter of 2012, i.e., the period when the two VLTROs were announced and settled. It also corresponds to the period in which sovereign funding stress peaked. We include interaction terms of $\rho_{i t}$ and two respective dummy variables (early sov. crisis and VLTRO) at the same time. This allows us to check whether the marginal impact of risk-shifting incentives as measured via $\rho_{i t}$ increased during the VLTRO period as compared with earlier stages of the sovereign debt crisis. Indeed, the results presented in column 3 show that while the mechanism sketched in our model was operating already in the early crisis period, it intensifies considerably in the final quarter of 2011 and the first quarter of 2012 19 A back-of-the-envelope calculation on the basis of specification (3) suggests that the mechanism is economically important, explaining approximately 53 percent of the observed domestic sovereign bond purchases during the VLTRO period 20

\footnotetext{
${ }^{19}$ Further cross-checks reveal that the strongest relation between $\rho_{i t}$ and the net purchases of domestic sovereign bonds is observed for the time period surrounding the settlement of the two credit operations with a maturity of three years (in the first quarter of 2012, as the first VLTRO was settled in January and the second in March 2012).

${ }^{20}$ As reported in table 1 the average net purchases of domestic sovereign bonds scaled by main assets during the VLTRO period is 0.2299 percent. The contribution of $\rho_{i t}$ in the same period is calculated by multiplying 1.6178 (the average of $\rho_{i t}$ during the period) with the sum of the coefficient of $\rho_{i t}$ and its interaction
} 
Note that all specifications allow for the possibility that a sovereign risk shock or a change in the strength of the bank-sovereign nexus can affect bank portfolio choices directly, over and above their interaction. Throughout all specifications, the coefficient on the sovereign CDS is also significant and has a negative sign. This finding indicates that the relationship between sovereign credit risk premiums and bank purchases of domestic sovereign bonds depends on the strength of banks' nexus with their sovereign. In the absence of a bank-sovereign nexus (i.e., when $\gamma_{i t}$-and therefore $\rho_{i t}$-is close to zero) banks scale down their domestic sovereign bond portfolios when sovereign credit risk premiums increase, as the increased risk is internalized by the bank. For higher levels of the bank-sovereign nexus, however, less of the increased domestic sovereign risk is internalized and the attractiveness of the higher nominal yield eventually dominates, thereby leading to higher purchases of domestic sovereign bonds.

Indeed, for a nexus equal to the cross-sectional median during the VLTRO period, a 1 percentage point increase in sovereign CDS leads to purchases of domestic sovereign bonds relative to main assets of 0.033 percent per quarter 21 A CDS increase in the order of 3.5 percentage points - corresponding to the difference between German and Italian sovereign CDS spreads in that period-implies additional purchases of domestic sovereign bonds of 0.12 percent of main assets per quarter. Bearing in mind that on average such purchases amounted to 0.23 percent of main assets, the size of the coefficient is economically meaningful. In a similar vein, the strengthening of the bank-sovereign nexus during the VLTRO period is accompanied by an expansion of banks' portfolios of domestic sovereign bonds. While the impact of $\gamma_{i t}$ is negligible for CDS levels close to the

term with the VLTRO dummy (0.076). The contribution stands at 0.123 percent, i.e., amounts to approximately 53 percent of the observed net purchases of domestic sovereign bonds reported above.

${ }^{21}$ Recalling that $\rho$ is the product of $\gamma_{i}$ and $d_{i}^{s}$, specification (3) presented in table 2 implies that the relation between sovereign CDS and domestic sovereign bond purchases during the VLTRO period has the following form: $\left.\frac{\partial B_{i}}{\partial d_{i}^{s}}\right|_{V L T R O=1}=-0.01 \gamma_{i}+0.086 \gamma_{i}-0.037=0.076 \gamma_{i}-0.037$. The cross-sectional median of $\gamma_{i}$ during the VLTRO period is 0.9272 (see table 1). Therefore, $\left.\frac{\partial B_{i}}{\partial d_{i}^{s}}\right|_{V L T R O=1}=0.033$. 
cross-sectional mean in our sample, 22 this no longer holds for banks located in countries under stress. An increase in the nexus of one standard deviation (0.21; see lower panel of table 1), corresponds to additional purchases of domestic sovereign bonds in the order of 0.17 percent of bank main assets within one quarter for a bank located in Spain, 0.19 in Italy, and 0.8 in Portugal 23

\subsection{Robustness Analysis}

We now check whether the findings remain valid when additional control variables are included, before turning to the question of why the results obtained for the VLTRO period are stronger than those for the early sovereign crisis phase. To do that, we augment the specification presented in column 3, sequentially adding controls (see panel B of table 2). The fundamental findings that risk-shifting incentives as measured via $\rho_{i t}$ are important for explaining banks' purchases of domestic sovereign bonds during the sovereign crisis period and that such incentives were particularly strong during the VLTRO period carry through. While the importance of this mechanism for the VLTRO period is found to be robust, its relevance for the early sovereign crisis period turns out to be less convincing: the coefficient of the interaction term of $\rho_{i t}$ and the VLTRO dummy remains largely unchanged and significant throughout, while the interaction with the early sov. crisis dummy loses significance in some of the specifications.

An initial set of controls captures the structure of banks' balance sheets and bank size. These are lagged by one period to minimize potential endogeneity problems. The first variable refers to banks' access to stable funding. Banks with a smaller base of stable

\footnotetext{
${ }^{22}$ Recall that the CDS spreads on domestic sovereign bonds are included in demeaned form, therefore the variable $d_{i t}^{s}$ equals zero whenever the sovereign CDS are at their sample mean (across time and countries).

$\left.23 \frac{\partial B_{i}}{\partial \gamma_{i}}\right|_{d V L T R O=1}=-0.01 * d_{i}^{s}+0.086 * d_{i}^{s}-0.037=0.076 d_{i}^{s}-0.037$. For a $d_{i}^{s}$ of 2.7 percentage points (corresponding to the demeaned CDS on Spanish sovereign bonds during the VLTRO period) $\left.\frac{\partial B_{i}}{\partial \gamma_{i}}\right|_{d V L T R O=1}=0.17$; for a $d_{i}^{s}$ of 3 percentage points (corresponding to the demeaned CDS on Italian sovereign bonds during the VLTRO period) $\left.\frac{\partial B_{i}}{\partial \gamma_{i}}\right|_{d V L T R O=1}=0.19$; for a $d_{i}^{s}$ of 11 percentage points (corresponding to the demeaned CDS on Portuguese sovereign bonds during the VLTRO period) $\left.\frac{\partial B_{i}}{\partial \gamma_{i}}\right|_{d V L T R O=1}=0.8$.
} 
funding might have been inclined to tilt their portfolio composition towards liquid assets, such as domestic sovereign bonds, in order to buffer funding shocks. We therefore include each bank's share of core deposit funding in column 4 . The variable is not significant and does not materially affect the size or significance of the coefficient of the interaction terms $\rho_{i t} * V L T R O$ and $\rho_{i t} *$ early sov. crisis. The second control refers to bank size, which may affect banks' propensity to take on exposure to domestic government debt, as larger banks may factor in a higher probability of being bailed out by the government in case of need, due to the potential systemic fallout of allowing them to fail - the "too big to fail" problem. Similar to what we find for the share of core deposit funding, bank size (defined as the logarithm of banks' main assets) is not significant and does not materially affect the size or significance of the coefficient of the two interaction terms (column 5).

Subsequently, in column 6, we control for banks' capital base. The variable - labeled leverage ratio - is a ratio of capital and reserves reported by banks in the context of the compilation of the monetary statistics over main assets. Banks with a weaker capital position might have stronger incentives to acquire domestic sovereign bonds, as the fraction of losses that will not be absorbed by shareholder equity and thus effectively shifted to bank creditors increases 24 This is among the driving factors of carry trades identified by Acharya and Steffen (2015). By contrast, our analysis suggests that banks' capital position does not have a statistically significant role in determining government bond purchases. This finding is in line with the evidence reported in Becker and Ivashina (2018). These authors, however, interpret this finding as evidence against the risk-shifting hypothesis, as, following Crosignani (2015) and Drechsler, Drechsel, and Marques-Ibanez (2016), they consider

\footnotetext{
${ }^{24}$ In addition, banks with low capital buffers may be inclined to purchase sovereign bonds, as the calculation of regulatory capital ratios uses a zero risk weight for sovereign exposures vis-à-vis euro-area governments (although this consideration is not captured by the variable used for capital, which is a leverage ratio that does not take into account the risk weights of the assets held). While this would explain why sovereign bonds are preferred to lending to the private sector (in which case scarce bank capital will need to be set aside), it does not per se imply that domestic sovereign bonds would be more attractive than bonds issued by other euro-area countries.
} 
that risk shifting should be associated with less-capitalized banks. In our analysis, instead, bank capitalization enters as a control, whereas the intensity of the motive to risk-shift is captured by the banksovereign nexus variable. In this context, it is nevertheless plausible that the intensity of the nexus would be stronger for less-capitalized banks, as the pricing of their riskiness would rely more heavily on the availability of a sovereign capital backstop 25

In a next step, we control for banks' existing holdings of liquid assets. The liquidity ratio includes interbank lending, holdings of government bonds, of debt securities issued by the private sector (including banks), and of equity. Banks that already hold large quantities of safe and liquid assets - which are also eligible for inclusion in the calculation of regulatory liquidity ratios - might be less inclined to purchase sovereign bonds. This is found to be the case (see column 7). The size of banks' pre-existing sovereign bond portfolio scaled by main assets is included for a similar reason. We find evidence of "mean reversion" in the sense that banks that already hold large quantities of domestic sovereign bonds tend to purchase less of these bonds (see column 8). Note that while the coefficient of the interaction term $\rho_{i t} * V L T R O$ remains significant also in this specification, the one of $\rho_{i t} *$ early sov. crisis does not.

We then include real GDP growth in the economy where each bank is located. As discussed in section 2, the state of the economy affects the balance sheets of both banks and the government, thereby imparting a correlation in their respective probabilities of default. At the same time, real GDP growth may act as a proxy for the ex ante risk-adjusted attractiveness of alternative domestic assets, such as loans to firms and households, effectively capturing the opportunity costs of holding sovereign debt. The result in column 9 does not reveal a significant influence of this factor on banks' decisions to purchase domestic sovereign bonds, although the sign of the estimated coefficient conforms with the reasoning for including this variable.

We subsequently include two other plausible proxies for the availability of alternative investment opportunities. First, we use a

\footnotetext{
${ }^{25}$ The relevant period predates the introduction of the Bank Resolution and Recovery Directive, which requires creditor bail-in before public capital support can be deployed.
} 
measure of demand for bank loans in the country where each bank is located based on the ECB's Bank Lending Survey. It is defined as the difference between the sum of the percentages of banks reporting that demand for loans has "increased considerably" and "increased somewhat" and the sum of the percentages of banks responding that it "decreased somewhat" and "decreased considerably." Its inclusion does not affect the results materially (see column 10). Finally, we include the unemployment rate prevailing in the country where banks are located and report the results in column 11. This variable seems to capture scarce fiscal space accompanied by elevated sovereign credit risk: its coefficient is significant and negative and its inclusion renders the direct impact of $d_{i}^{s}$ no longer significant. Moreover, the coefficient of the interaction term $\rho_{i t} *$ early sov. crisis turns insignificant. The coefficient of the interaction term between $\rho_{i t}$ and the VLTRO dummy remains significant at the 1 percent level.

Our results remain robust when including interaction terms of $\rho_{i t}$ and the control variables (see table 3) and of the bank-specific characteristics with the VLTRO period dummy (see table A5 in Andreeva and Vlassopoulos 2016 26 ). The significance and size of $\rho_{i t} * V L T R O$ are barely affected. It is noteworthy that we do not find evidence of stronger purchases of domestic sovereign bonds by weakly capitalized lenders during the VLTRO period. This suggests that risk-shifting incentives due to the existence of a bank-sovereign nexus rather than a more general "gambling for resurrection" motive by undercapitalized banks explain the observed surge in banks' domestic sovereign bond purchases.

In a next set of robustness analyses, we include all bank-level controls and the unemployment rate at the same time (see table 4. column 1) and add one by one a set of variables capturing the changes in banks' funding. We consider the flows of core deposits

\footnotetext{
${ }^{26}$ This working paper version in addition shows that our main results remain largely unchanged when estimating the model using OLS and country fixed effects. Fixed-effects panel estimations rely on the time variability of explanatory variables. The significance of factors that differ across cross-sectional units but remain rather stable over time is absorbed by the bank fixed effects. By contrast, OLS allows us to identify the impact of variables that vary less strongly over time at the expense of potential omitted variable bias due to unobserved bank-specific characteristics.
} 


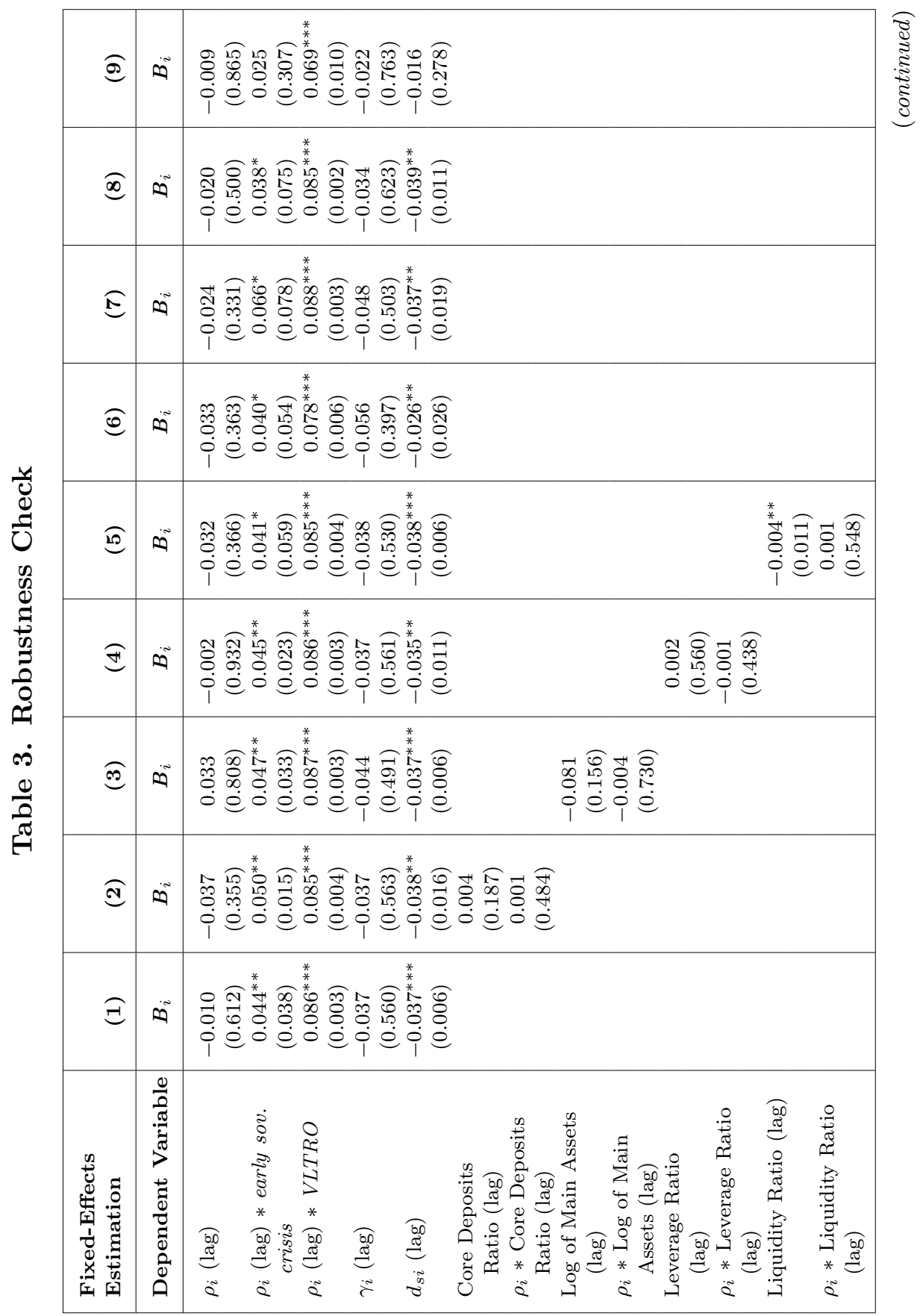




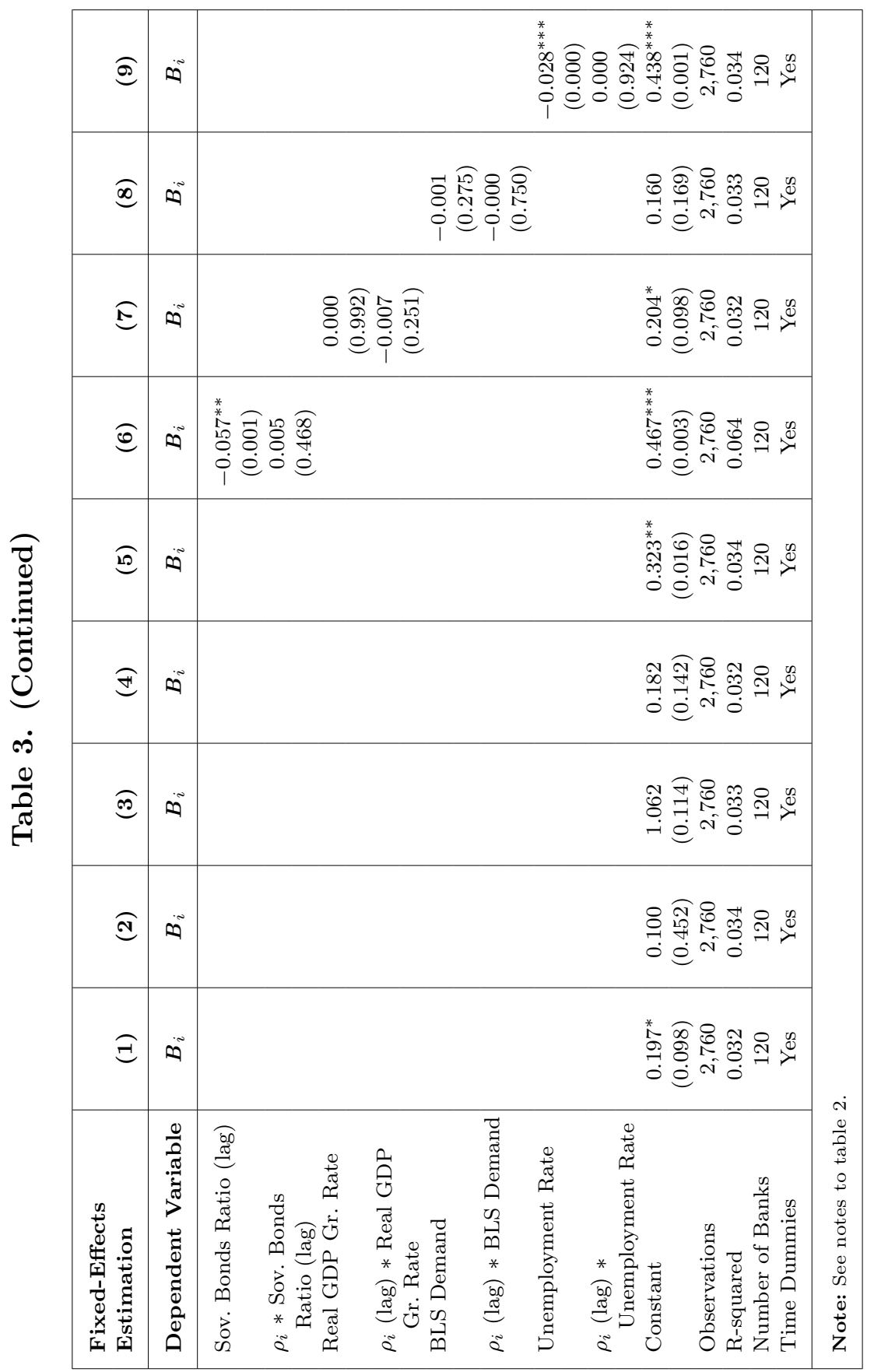




\begin{tabular}{|c|c|c|}
\hline 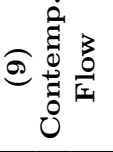 & $\ddot{\theta}$ & 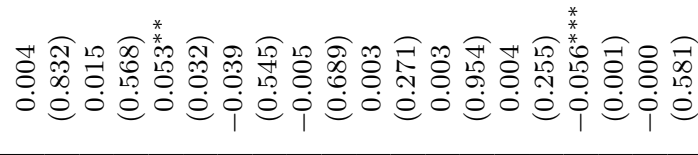 \\
\hline 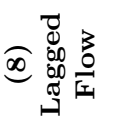 & $\dot{\theta}$ & 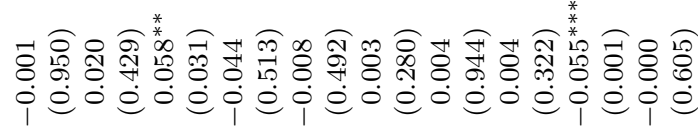 \\
\hline 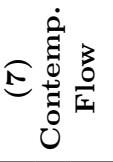 & $\infty$ & 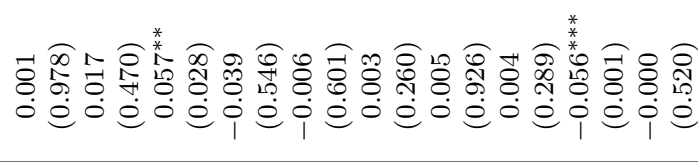 \\
\hline 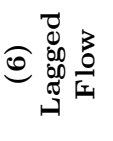 & $\infty$ & 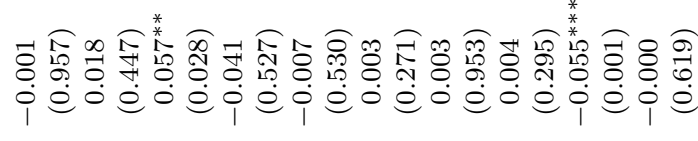 \\
\hline 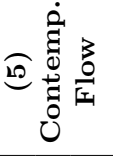 & $\infty$ & 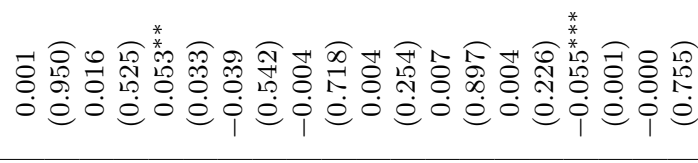 \\
\hline 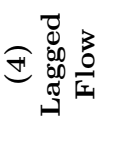 & $\infty$ & 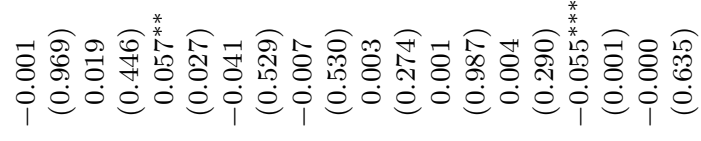 \\
\hline 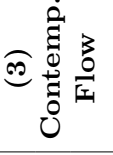 & $\infty$ & 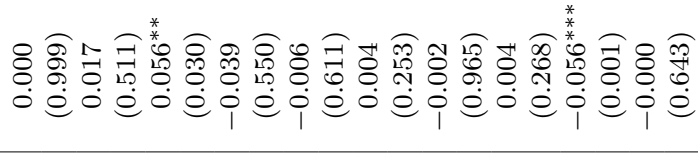 \\
\hline 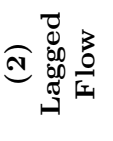 & $\infty$ & 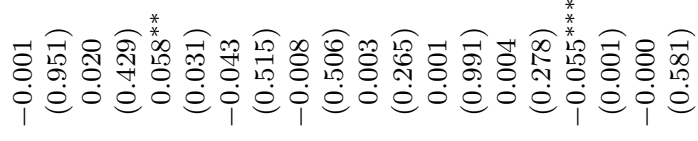 \\
\hline 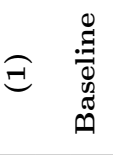 & $\infty$ & 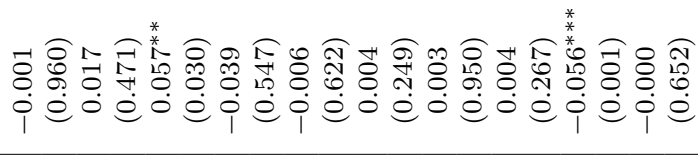 \\
\hline 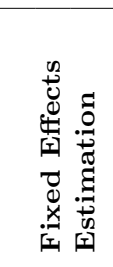 & 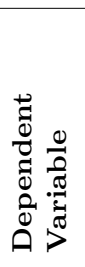 & 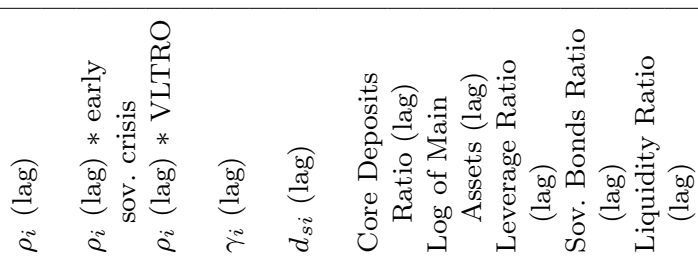 \\
\hline
\end{tabular}




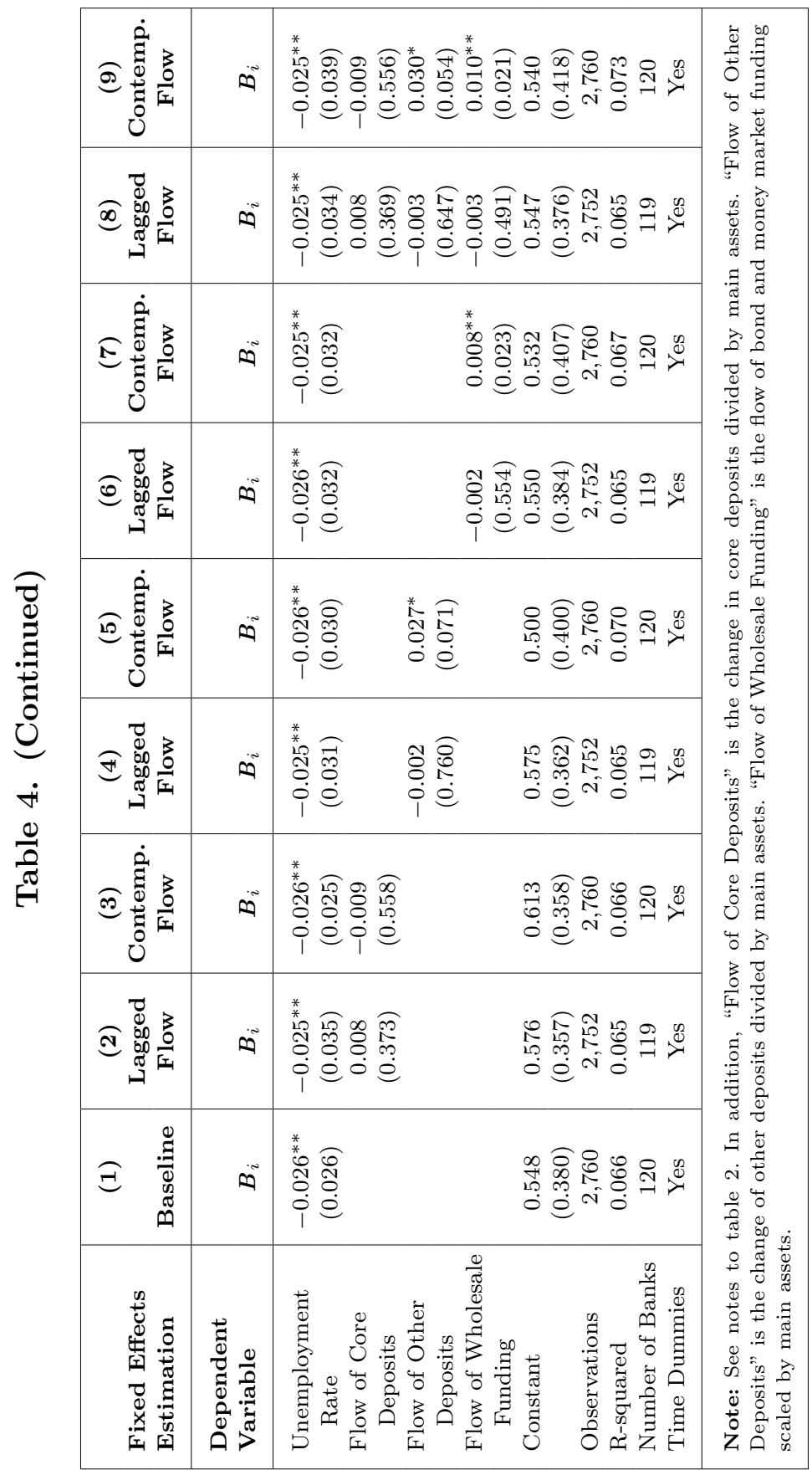


to capture the effect of changes in the availability of stable funding and the flows of other deposits and wholesale funding to capture the impact of changes in more-volatile funding components. A bank that has seen an unanticipated inflow of funds would need to ceteris paribus "park" these funds until they are deployed towards a more permanent use 27 In this regard, domestic sovereign bonds are a natural choice, since the sovereign bond portfolio can be expanded or scaled down quickly and with small transaction costs.

We augment the baseline in column 1 using lags of the funding flow variables. The inclusion of funding flows does not materially affect the size or significance of our main variables of interest $\left(\rho_{i t} *\right.$ early sov. crisis and $\left.\rho_{i t} * V L T R O\right)$. None of the lagged flows added to the baseline specification are significant when included on their own (see columns 2, 4, and 6) or all at the same time (column 8). As the "parking" of unanticipated flows is likely to take place very quickly, using lagged quarterly funding flows may disconnect the timing of the funding shock and the associated asset expansion. We, therefore, also use contemporaneous flows in a set of alternative specifications (columns 3, 5, 7, and 9), which, however, may suffer from endogeneity problems. We find a significant relation between domestic sovereign bond purchases and increases in volatile funding sources (wholesale funding and other deposits). Banks may be unwilling to expand their loan portfolios on the basis of funding inflows that may quickly reverse, as argued, for instance, by Butt et al. (2014). Instead, part of these inflows seems to have been used to build up liquidity buffers in the form of domestic sovereign bonds. Core deposits, on the other hand, seem not to relate to banks' purchases of sovereign bonds. As these flows are sticky and do not expose the recipient to the risk of an unexpected sharp reversal, they seem not to be accompanied by an accumulation of precautionary liquidity buffers.

\subsection{Why Is the VLTRO Period Special?}

We now turn to the question of why we find evidence for risk shifting in domestic sovereign bonds between the final quarter of 2011 and

\footnotetext{
${ }^{27}$ Repaying some of its outstanding liabilities is also a possible adjustment channel.
} 
the first quarter of 2012 while the relation turns out not to be robust outside this period. There are two readings of this result.

A benign interpretation would suggest that banks were eager to build up liquidity buffers in this period. Within the category of assets that can serve this purpose, risk-shifting incentives as defined in our theoretical analysis simply rendered domestic sovereign bonds as the option with the best risk-return profile. The VLTROs were introduced in a period of financial market turbulence. Banks that were facing funding pressure or feared that funding pressure might materialize in the not-too-distant future might have been inclined to borrow from these operations and to expand their stock of assets that can be easily sold or deposited with the Eurosystem. Banks' attempt to frontload the refinancing of maturing long-term bonds at the VLTROs has already been documented (ECB 2012). Such an "on-balance-sheet" liquidity buffer can be maintained in several forms. The strong correlation between bank and sovereign credit risk and elevated credit risk premiums in sovereign funding costswhich were indeed prevalent during this episode - merely implied that investments in domestic sovereign debt dominate in terms of their risk-return characteristics the two next best alternatives: holding excess reserves with the Eurosystem or holding other sovereign bonds denominated in euros. While the predominant motivation of banks in that particular period might have been to self-insure against liquidity risk, investments in domestic sovereign bonds were the best option, allowing banks - as a side effect - to generate a positive carry spread on top 28 A less benign interpretation would suggest that the availability of long-term funding at a price that is not sensitive to banks' own risk profile allowed them to actively pursue carry trades with profit generation as the primary motive, a view supported, for instance, by Acharya and Steffen (2015).

In what follows we try to shed some light on this question by including measures of banks' recourse to Eurosystem credit operations - the ratio of three-year LTRO credit to main assets and

\footnotetext{
${ }^{28}$ In a recent paper that postdates this analysis, Crosignani, Faria-e-Castro, and Fonseca (2017) show that the VLTROs had a causal effect on the incentives of Portuguese banks to purchase domestic sovereign bonds due to liquidity risk management motives as opposed to carry trades. It is noteworthy that these authors find that banks tended to prefer maintaining this liquidity buffer in the form of securities with a maturity comparable to the maturity of the VLTRO.
} 
the overall flow of Eurosystem credit scaled by main assets. We would expect to find a robust and statistically significant positive relation between banks' borrowings from the Eurosystem and their domestic sovereign bond purchases in the case of deliberate carrytrade strategies. The measures of recourse to Eurosystem credit are included first on their own, subsequently interacted with the VLTRO time dummy - to see whether a positive relation emerges during that period - and finally interacted with our main variable of interest $\rho_{i t}$ - to see whether access to long-term risk insensitive funding has worsened already existing incentives for risk shifting as captured by our measure $\rho_{i t}$. The results are presented in table 5 . All specifications include the full set of control variables featured in table 4.

Panel A of the table focuses on banks' bids in the three-year LTROs. Column 2 features only the ratio of outstanding three-year LTRO credit to main assets; in column 3 we also include its interaction with the VLTRO dummy and in column 4 its interaction with $\rho_{i t}$. This allows us to examine whether banks used the two three-year LTRO operations to pursue carry trades. The results do not support this hypothesis. Banks' borrowings from the three-year LTROs are not a significant determinant of their domestic sovereign bond purchases in general, nor specifically during 2011:Q4 and 2012:Q1. In addition, we find no evidence that banks for which the risk-shifting motive was particularly strong (captured by a high $\rho_{i t}$ ) were in fact funding their purchases using VLTRO credit - the coefficient of the interaction term of $\rho_{i t}$ and the variable 3 year LTRO turns out not to be statistically significant.

The other panels of table 5 use the flow of Eurosystem credit: panel $\mathrm{B}$ includes all funding flow variables as lags, while panel $\mathrm{C}$ takes contemporaneous funding flows. Again, we present one specification, in which the flow of Eurosystem credit is included on its own, a subsequent specification that features in addition its interaction with the VLTRO dummy, and a final one - with an interaction term with $\rho_{i t}$. The lagged flow of Eurosystem credit when interacted with the VLTRO dummy seems to significantly relate to banks' expansion of domestic sovereign bond portfolios (column 6 ). In addition, we find a significant positive relationship between the contemporaneous flow of Eurosystem credit and domestic sovereign bond purchases (see columns 8,9, and 10). The strength of the 


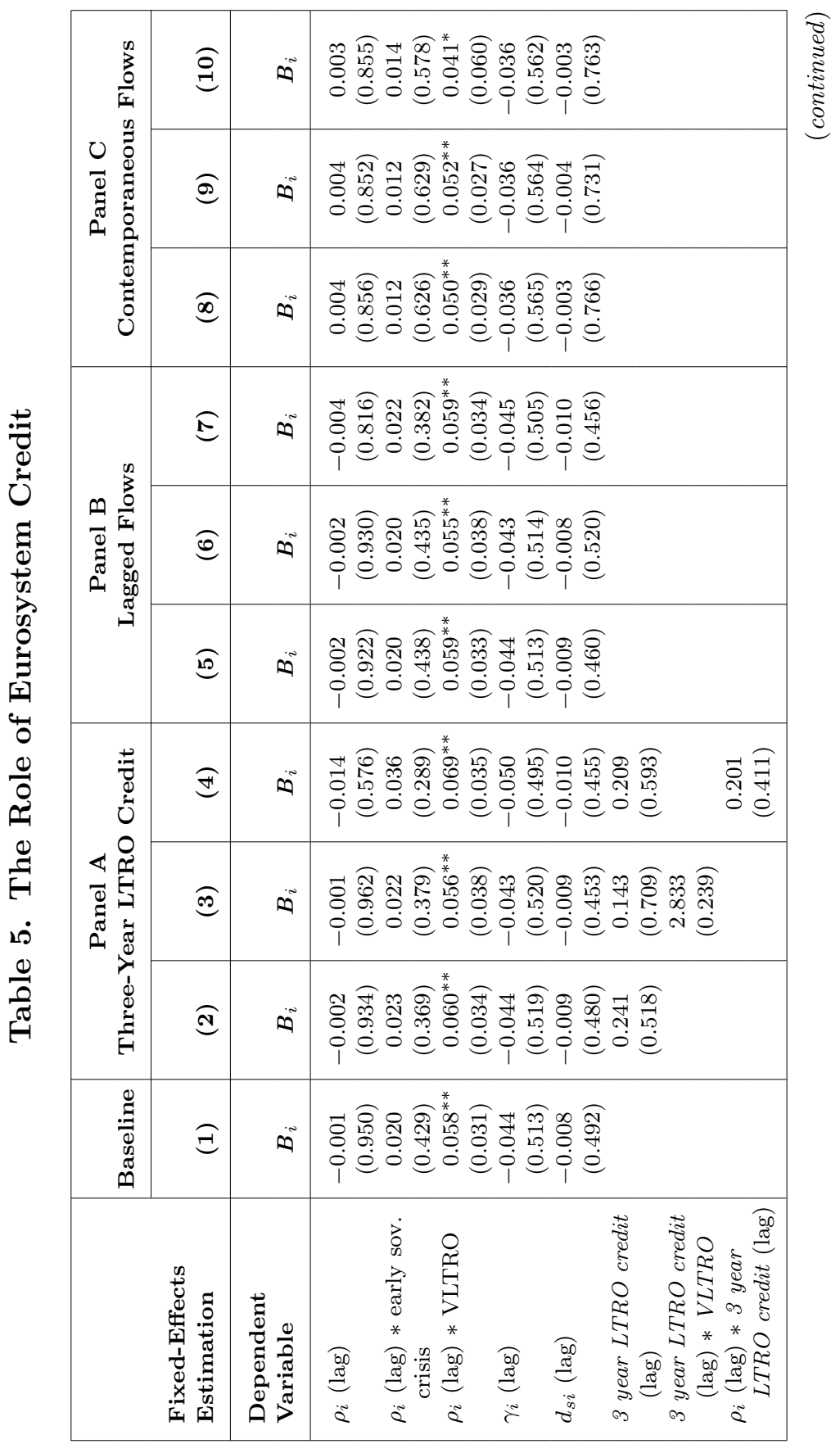




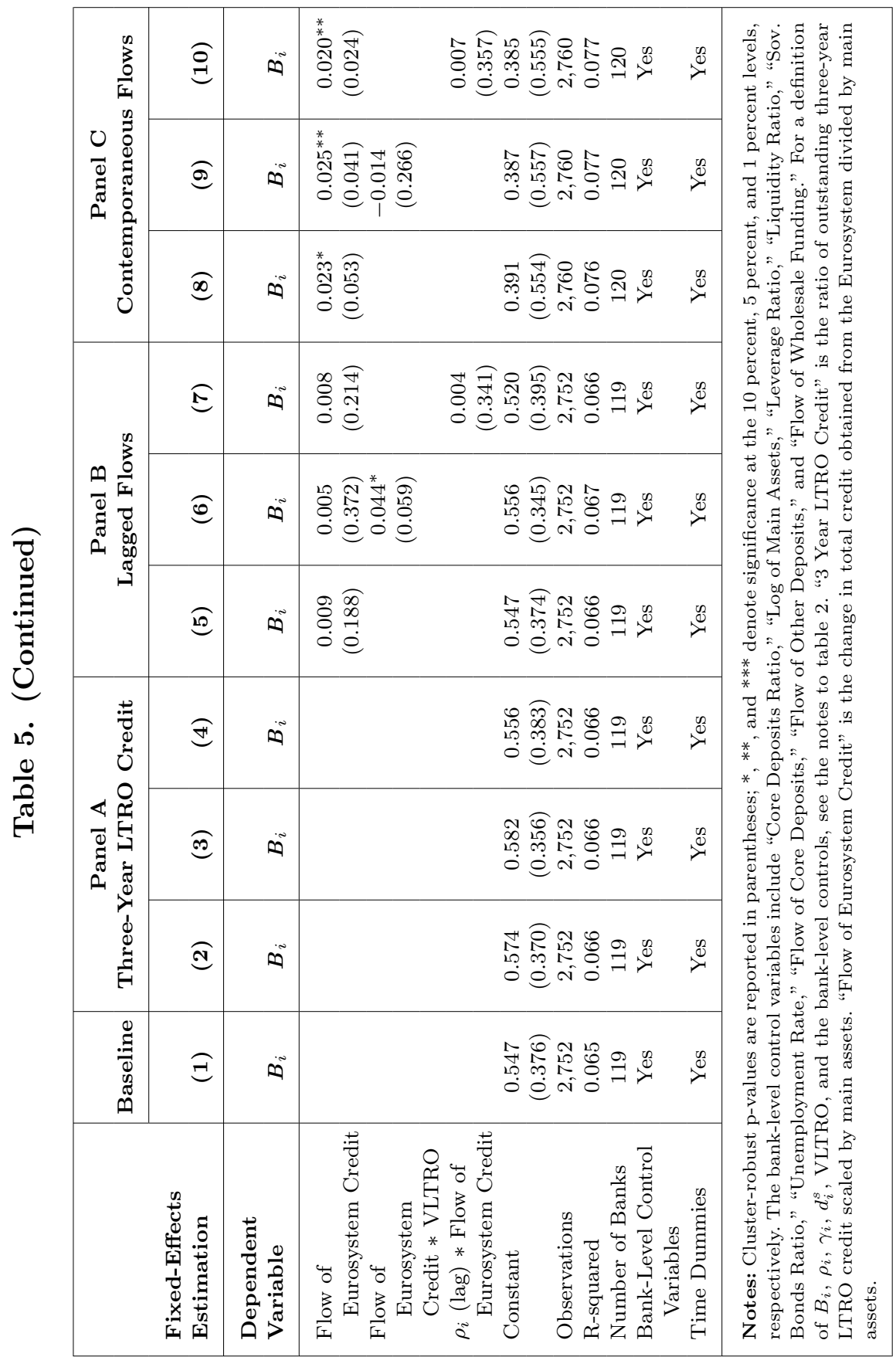


relationship has the same order of magnitude as the one of the flow of other deposits or wholesale funding. This finding speaks in favor of the "benign" precautionary motive for the induced purchases of sovereign bonds. If a pure "carry trade" motive as in Acharya and Steffen (2015) was the driving force, given that central bank liquidity was supplied elastically as to fully accommodate banks' demand (subject to the availability of eligible collateral), one would expect a coefficient much closer to 1 .

Throughout the specifications presented in table 5, the size and significance of the coefficient of the interaction term $\rho_{i t} * V L T R O$ remain by and large unchanged compared with the baseline (1). To sum up, the observed strong expansion of banks' domestic sovereign bond portfolios during the final quarter of 2011 and the first quarter of 2012 seems to reflect banks' attempts to build up liquidity buffers and - to a much lesser extent - the active pursuit of carry trades. In both cases, the risk-shifting mechanism meant that acquisitions of domestic sovereign bonds were a strategy that offered higher ex ante returns than alternatives, such as the acquisition of non-domestic sovereign bonds.

\section{Conclusions}

We find evidence of risk shifting via acquisitions of domestic sovereign bonds in the final quarter of 2011 and first quarter of 2012 - an episode of marked increases in domestic sovereign bond portfolios by euro-area banks located in vulnerable countries. For this period, we show that if banks' creditworthiness is correlated with that of their domestic sovereign, surges of sovereign credit risk lead to expansions of banks' exposures to their government. Furthermore, in the presence of sovereign credit risk, banks' tendency to purchase domestic sovereign debt increases with a stronger bank-sovereign nexus.

Risk-shifting behavior emerges in the period following the conduct of the VLTROs by the ECB, as this period featured the coexistence of, on the one hand, elevated sovereign credit risk and, on the other, a significant intertwining of bank and sovereign creditworthiness. In these circumstances, the risk-shifting mechanism implies that acquiring domestic sovereign bonds dominates, from the perspective of bank shareholders, alternative ways to maintain an 
on-balance-sheet liquidity buffer, or indeed to execute carry trades, such as investing in non-domestic government bonds. Our findings are, therefore, consistent with banks' home bias in the purchases of sovereign bonds reflecting an incomplete internalization of domestic sovereign credit risk.

\section{References}

Acharya, V., I. Drechsler, and P. Schnabl. 2014. "A Pyrrhic Victory? Bank Bailouts and Sovereign Credit Risk." Journal of Finance 69 (6): 2689-2739.

Acharya, V., and R. G. Rajan. 2013. "Sovereign Debt, Government Myopia, and the Financial Sector." Review of Financial Studies 26 (6): 1526-60.

Acharya, V., and S. Steffen. 2015. "The 'Greatest' Carry Trade Ever? Understanding Eurozone Bank Risks." Journal of Financial Economics 115 (2): 215-36.

Altavilla, C., M. Pagano, and S. Simonelli. 2017. "Bank Exposures and Sovereign Stress Transmission." Review of Finance 21 (6): 2103-39.

Andreeva, D. C., and T. Vlassopoulos. 2016. "Home Bias in Bank Sovereign Bond Purchases and the Bank-Sovereign Nexus." ECB Working Paper No. 1977.

Angelini, P., G. Grande, and F. Panetta. 2014. "The Negative Feedback Loop between Banks and Sovereigns." Questioni di Economia e Finanza No. 213, Bank of Italy.

Attinasi, M.-G., C. Checherita, and C. Nickel. 2010. "What Explains the Surge in Euro Area Sovereign Spreads during the Financial Crisis of 2007-09?" Public Finance and Management 10 (4): 595-645.

Bank of Italy. 2012. Financial Stability Report. No. 4 (November). 2013. Financial Stability Report. No. 6 (November).

Battistini, N., M. Pagano, and S. Simonelli. 2014. "Systemic Risk, Sovereign Yields and Bank Exposures in the Euro Crisis." Economic Policy 29 (78): 205-41.

Becker, B., and V. Ivashina. 2018. "Financial Repression in the European Sovereign Debt Crisis." Review of Finance 22 (1): 83-115. 
Bertrand, M., E. Duflo, and S. Mullainathan. 2004. "How Much Should We Trust Differences-in-Differences Estimates?" Quarterly Journal of Economics 119 (1): 249-75.

Bolton, P., and O. Jeanne. 2011. "Sovereign Default Risk and Bank Fragility in Financially Integrated Economies." IMF Economic Review 59 (2): 162-94.

Bonner, C. 2016. "Preferential Regulatory Treatment and Banks' Demand for Government Bonds." Journal of Money, Credit and Banking 48 (6): 1195-1221.

Broner, F., A. Erce, A. Martin, and J. Ventura. 2014. "Sovereign Debt Markets in Turbulent Times: Creditor Discrimination and Crowding-out Effects." Journal of Monetary Economics 61 (C): $114-42$.

Butt, N., R. Churm, M. McMahon, A. Morotz, and J. Schanz. 2014. "QE and the Bank Lending Channel in the United Kingdom." Working Paper No. 511, Bank of England.

Cooper, R., and K. Nikolov. 2018. "Government Debt and Banking Fragility: The Spreading of Strategic Uncertainty." International Economic Review 59 (4): 1905-25.

Cornett, M. M., J. J. McNutt, P. E. Strahan, and H. Tehranian. 2011. "Liquidity Risk Management and Credit Supply in the Financial Crisis." Journal of Financial Economics 101 (2): 297312 .

Crosignani, M. 2015. "Why Are Banks Not Recapitalized During Crises?" Working Paper No. 203, Oesterreichische Nationalbank. Crosignani, M., M. Faria-e-Castro, and L. Fonseca. 2017. "The (Unintended?) Consequences of the Largest Liquidity Injection Ever." Finance and Economics Discussion Series No. 2017-011, Board of Governors of the Federal Reserve System.

Demirguc-Kunt, A., and H. Huizinga. 2004. "Market Discipline and Deposit Insurance." Journal of Monetary Economics 51 (2): 37599.

Dieckmann, S., and T. Plank. 2012. "Default Risk of Advanced Economies: An Empirical Analysis of Credit Default Swaps during the Financial Crisis." Review of Finance 16 (4): 903-34.

Drechsler, I., T. Drechsel, and D. Marques-Ibanez. 2016. "Who Borrows from the Lender of Last Resort?" Journal of Finance 71 (5): 1933-74. 
Ejsing, J., and W. Lemke. 2011. "The Janus-Headed Salvation: Sovereign and Bank Credit Risk Premia during 2008-2009." Economics Letters 110 (1): 28-31.

European Central Bank. 2012. "The Impact of the First Three-Year Longer-Term Refinancing Operation." Monthly Bulletin (January): Box 4.

European Systemic Risk Board. 2015. "ESRB Report on the Regulatory Treatment of Sovereign Exposures" (March).

Farhi, E., and J. Tirole. 2018. "Deadly Embrace: Sovereign and Financial Balance Sheets Doom Loops." Review of Economic Studies 85 (3): 1781-1823.

Gennaioli, N., A. Martin, and S. Rossi. 2014. "Sovereign Default, Domestic Banks, and Financial Institutions." Journal of Finance 69 (2): 819-66.

Gerlach, S., A. Schulz, and G. Wolff. 2010. "Banking and Sovereign Risk in the Euro Area." CEPR Discussion Paper No. 7833.

Holmstrom, B., and J. Tirole. 1993. "Market Liquidity and Performance Monitoring." Journal of Political Economy 101 (4): 678-709.

Horvath, B., H. Huizinga, and V. Ioannidou. 2015. "Determinants and Valuation Effects of the Home Bias in European Banks' Sovereign Debt Portfolios." CEPR Discussion Paper No. 10661. Jensen, M., and W. Meckling. 1976. "Theory of the Firm: Managerial Behavior, Agency Costs and Ownership Structure." Journal of Financial Economics 3 (4): 305-60.

Kallestrup, R., D. Lando, and A. Murgoci. 2016. "Financial Sector Linkages and the Dynamics of Bank and Sovereign Credit Spreads." Journal of Empirical Finance 38 (PA): 374-93.

Lucas, A., B. Schwaab, and X. Zhang. 2013. "Conditional and Joint Credit Risk." ECB Working Paper No. 1621.

McKinnon, R. 1973. Money and Capital in Economic Development. Washington, D.C.: Brookings Institution Press.

O'Kane, D. 2008. Modelling Single-Name and Multi-Name Credit Derivatives. Wiley Finance.

Popov, A., and N. van Horen. 2015. "Exporting Sovereign Stress: Evidence from Syndicated Bank Lending during the Euro Area Sovereign Debt Crisis." Review of Finance 19 (5): 1825-66. 
Radev, D. 2013. "Systemic Risk and Sovereign Debt in the Euro Area." SAFE Working Paper No. 37.

Shaw, E. 1973. Financial Deepening in Economic Development. New York: Oxford University Press.

Uhlig, H. 2014. "Sovereign Default Risk and Banks in a Monetary Union." German Economic Review 15 (1): 23-41. 